Revista de Derecho Público: Teoría y Método Marcial Pons Ediciones Jurídicas y Sociales Vol. 1 | 2021 pp. 7-52 Madrid, 2021

DOI:10.37417/RPD/vol_1_2021_531

(C) Luis Medina Alcoz ISSN: 2695-7191

Recibido: 17/11/2021 | Aceptado: 13/01/2021

\title{
HISTORIA DEL CONCEPTO DE DERECHO SUBJETIVO EN EL DERECHO ADMINISTRATIVO ESPAÑOL ${ }^{1}$
}

\author{
HISTORY OF THE CONCEPT OF SUBJETIVE RIGHT \\ WITHIN SPANISH ADMINISTRATIVE LAW
}

\author{
Luis Medina Alcoz \\ Profesor Titular de Derecho administrativo \\ de la Universidad Complutense \\ Letrado del Tribunal Constitucional \\ lmedinaa@ucm.es
}

RESUMEN: Bajo el influjo del liberalismo conservador, con el objetivo de construir un Estado amplio hegemonizado por la administración pública, el Derecho administrativo español desarrolló muy pronto la teoría de la doble personalidad estatal y, con ello, la distinción entre el derecho subjetivo ordinario o derecho subjetivo de carácter civil (posición jurídica frente al Estado, en cuanto persona civil situada en pie de igualdad, merecedora de plena protección judicial) y el derecho subjetivo de carácter administrativo o interés legítimo (posición jurídica frente a la administración en estado de mando merecedora de una protección administrativa menor en beneficio del interés general). A partir de los ańos cincuenta del siglo xx recuperó elementos clave del liberalismo genuino, entre ellos el concepto clásico (ordinario) de derecho subjetivo. La tendencia ha sido a que: (i) todo el Derecho administrativo objetivo sea derecho subjetivo bajo la condición de que el incumplimiento del primero afecte singularmente a quien esgrime el segundo en el proceso, con independencia de la finalidad de la norma; y (ii) quien sufre las extralimitaciones del poder, en cuanto titular de derechos, tenga garantizada una protección judicial plena con garantías de imparcialidad e igualdad de armas, así como la posibilidad de practicar prueba y obtener condenas a hacer. Al igual que en los ordenamientos vecinos, la ficción ha jugado un papel decisivo en esta evolución.

\footnotetext{
1 Trabajo finalizado el 17 de diciembre de 2020.
} 
PALABRAS CLAVE: historia del Derecho; Derecho administrativo; derecho subjetivo; interés legítimo; justicia administrativa; jurisdicción contencioso-administrativa; teoría de la norma protectora (Schutznormtheorie); recurso por exceso de poder (recours pour excès de pouvoir).

ABSTRACT: Under the influence of conservative liberalism and willing a broad State hegemonized by the public administration, Spanish Administrative Law very early developed the theory of the dual state personality and the resulting distinction between ordinary subjective right or subjective right of civil character (legal position vis-à-vis the State, as a civil person situated on an equal footing, deserving full judicial protection) and subjective right of an administrative nature or legitimate interest (legal position vis-à-vis the administration in command state deserving of minor administrative protection because of the general interest). However, from the fifties of the twentieth century Spanish Administrative Law has recovered key elements of genuine liberalism, including the classical (ordinary) concept of subjective right. The trend has been for: (i) every norm of Administrative Law is a subjective right under the condition that the breach of the first one affects whoever wields the second one in the process, regardless of the purpose of that rule; and (ii) whoever suffers infringements is holder of rights and therefore deserves full judicial protection with guarantees of impartiality and equality of arms, as well as the possibility of taking evidence and obtaining convictions. As in neighboring legal systems, fiction has played a decisive role in this evolution.

KEYWORDS: history of Law; Administrative Law; right, legitimate interest; administrative justice; contentious-administrative jurisdiction; Schutznormtheorie; recours pour excès de pouvoir.

SUMARIO: 1. PRESENTACIÓN.- 2. DEL ESTADO LIBERAL AL ESTADO AUTORITARIO.

2.1. Liberalismo clásico y afirmación del derecho subjetivo. 2.2. Liberalismo conservador y negación del derecho subjetivo frente a la potestad administrativa. 2.2.1. Planteamiento general y contexto europeo. 2.2.2. El derecho subjetivo de carácter administrativo como derecho "secundario" o "imperfecto". 2.3. Crisis del liberalismo y negación del derecho subjetivo como categoría.-3. DEL ESTADO AUTORITARIO AL ESTADO CONSTITUCIONAL. 3.1. La protección de los derechos: el derecho subjetivo como autonomía de la voluntad. 3.1.1. La recuperación del concepto iusnaturalista de derecho subjetivo, en general. 3.1.2. La recuperación del concepto iusnaturalista de derecho subjetivo en el Derecho administrativo español, en particular.3.2. La regulación de los derechos: el derecho subjetivo como interés jurídicamente protegido.- 4. CONCLUSIONES.— 5 BIBLIOGRAFÍA

\section{PRESENTACIÓN}

El presente estudio aborda la historia del concepto de derecho subjetivo dentro del Derecho administrativo. Se refiere específicamente al ordenamiento español, enmarcándolo dentro del contexto europeo, sin la pretensión de historiar el Derecho de otros países. Distingue dos etapas fundamentales: del Estado liberal al Estado autoritario, esto es, el tiempo transcurrido entre las Cortes de Cádiz y el franquismo autárquico; y del Estado autoritario al Estado constitucional, que va del franquismo de la segunda posguerra mundial hasta principios del siglo XXI. 
La periodización escogida es convencional, como lo son todas. Se corresponde con dos grandes tendencias a las que ha estado sometido el Derecho administrativo y que han tenido particular reflejo en el concepto de derecho subjetivo. La primera impulsó el nacimiento mismo del Derecho administrativo en el siglo xIx y culminó con el Derecho administrativo "fascistizado" de los años cuarenta de la centuria siguiente; consistió, muy resumidamente, en un proceso de relativización y rechazo de las garantías liberales que habían elaborado la Escuela de Derecho natural en sus diversas variantes. La segunda empezó durante la década siguiente y halló un renovado impulso durante los primeros ańos del sistema constitucional de 1978; consistió en un proceso de recuperación de los axiomas liberales, pero con múltiples adaptaciones, vinculadas en última instancia a la imposibilidad de desarmar a una administración que tenía encomendada una cantidad enorme y muy variada de tareas para conformar la vida social. En la actualidad parece que la tendencia es ya otra, pero es pronto para calibrar su repercusión sobre el concepto de derecho subjetivo del Derecho administrativo español ${ }^{2}$.

La construcción de una teoría del derecho subjetivo en el Derecho administrativo vigente no puede limitarse a analizar sin más los diferentes conceptos para afirmar la superioridad técnica de unos sobre otros. Exige comprender primero por qué surgió la noción, el problema que a su través quiso resolverse, así como las concepciones del mundo y vicisitudes que condicionaron su formulación ${ }^{3}$. El concepto de derecho subjetivo ha nacido y se ha desarrollado como expresión, consecuencia o derivación lógica de concepciones políticas sobre el sentido y la justificación del poder público y de sus productos normativos, por lo que las elaboraciones teóricas de Derecho vigente deben partir de análisis históricos como el aquí propuesto. Ahora bien, el presente estudio desarrolla una investigación estrictamente histórica. No pretende teorizar el significado preciso de los significantes "derecho subjetivo" e "interés legítimo" que lucen en la Constitución y en múltiples textos del Derecho positivo, incluidos los más significativos ${ }^{4}$.

${ }^{2}$ Explico ampliamente estas tendencias y el sentido de la periodización propuesta en la monografía que, próximamente, publicará Marcial Pons: Historia del Derecho administrativo español; es la ampliación de dos capítulos escritos para el Tratado de Derecho administrativo, vol. 1, dirigido por José María RODRÍGUEZ DE SANTIAGO, Gabriel DOMÉNECH PASCUAL y Luis ARROYO JIMÉNEZ, también en prensa.

3 Hago mía la tesis central de Riccardo ORESTANO, Azione, diritti soggettivi, persone giuridiche, Il Mulino, Bologna, 1978, pp. 178-189.

${ }^{4}$ He abordado la cuestión también desde la perspectiva del Derecho vigente en un trabajo respecto de cuya parte histórica la presente contribución es en cierto modo una prolongación: Luis MEDINA ALCOZ, Libertad y autoridad en el Derecho administrativo. Derecho subjetivo e interés legitimo: una revisión, Marcial Pons, Madrid, 2016. Sintetizó aquí los resultados de aquella investigación, centrándola todavía más en el Derecho español y enriqueciéndola con nuevas fuentes. 


\section{DEL ESTADO LIBERAL AL ESTADO AUTORITARIO}

\subsection{Liberalismo clásico y afirmación del derecho subjetivo}

Conforme al paradigma liberal de finales del siglo xviII, el Estado debía ajustar sus regulaciones a una "ley general de libertad", limitándose, en consecuencia, a determinar "el conjunto de condiciones bajo las cuales el arbitrio de uno puede ser compatible con el arbitrio de otro" ${ }^{5}$. Si imponía una obligación a un sujeto había de ser, necesariamente, para garantizar la libertad de otro. Por eso toda obligación legalmente impuesta a un individuo implicaba de suyo el derecho subjetivo correlativo de otro, esto es, un ámbito de autonomía atribuido al acreedor para conducirse libremente conforme a intereses o fines elegidos por él, un espacio que el deudor debía respetar absteniéndose de una determinada conducta o realizando el comportamiento debido. La obligación y el derecho eran pues conceptos simétricos, caras de una misma moneda (principio de correlatividad o bilateralidad). Comoquiera que no había más intervención posible que la destinada a garantizar la libertad individual, las leyes debían limitarse a establecer obligaciones y derechos correlativos. El Derecho objetivo era así nada más que un sistema de obligaciones y derechos. Los conceptos de Derecho objetivo, obligación y derecho subjetivo eran en realidad perfectamente intercambiables, se referían a una misma cosa. Ahora bien, el concepto básico y preferible era el tercero, pues era lógica y axiológicamente prioritario a los demás, era el ámbito de libertad originaria a cuyo servicio el Estado había restringido la autonomía o la libertad de otro. En fin, el derecho subjetivo encerraba en sí como carácter esencial la exigibilidad. No podía aceptarse el derecho sin acción. Hacerlo habría supuesto rechazar la premisa liberal o, lo que es lo mismo, permitir que el Estado desprotegiera a un individuo frente a las agresiones de otro. Por eso la acción procesal era una desinencia del derecho subjetivo. En fin, el concepto de derecho subjetivo incluía la exigencia de un proceso paritario conducido por jueces independientes destinado a remediar por completo la vulneración: "la libertad individual no puede existir si los jueces no son absolutamente independientes del gobierno" ${ }^{6}$. La ley, si establecía un derecho subjetivo para proteger la libertad del titular frente al comportamiento del obligado que podría perturbarla, debía necesariamente establecer garantías procesales simétricas y asegurar su plena realización práctica.

Tal es, muy esquemáticamente, la teoría general del Derecho de la Escuela de Derecho Natural, formulada después con suma precisión por los iusprivatistas del siglo $\mathrm{XIX}^{7}$. El Derecho español, alineado también en este punto con la cultura ju-

\footnotetext{
5 Immanuel KANT, Introducción a la teoría del Derecho, CEPC, Madrid, 1978 (original de 1797), p. 80.

6 Ramón SALAS CORTÉS, Lecciones de Derecho público constitucional, CEPC, Madrid, 1982 (original de 1821), p. 61.

7 Me refiero específicamente a la teoría del derecho subjetivo elaborada en la cultura jurídica romanística (por ejemplo, DÉMOLOMBE, COUCHE, JOSSERAND o COVIELLO) y en el entorno germánico: Friedrich Karl von SAVIGNY, Sistema del Derecho romano actual, Góngora y Compañía, Madrid, 1878 (original de 1840-1849); Bernhard WINDSCHEID, Die Actio des römischen Civilrechts,
} 
rídica europea, desarrollaba estos planteamientos. Está expresado muy claramente en textos imbuidos del genuino liberalismo gaditano (el proyecto de Código civil de 1821 es el más significativo ${ }^{8}$ ). También lo está en escritos exponentes del liberalismo conservador. Por ejemplo, de acuerdo con BORDIÚ Y GÓNGORA: "el hombre es un ser individual [y en cuanto tal] tiene derecho á poner en ejercicio su voluntad, que es en lo que consiste la libertad. Esta palabra derecho de un hombre á poner en ejercicio su voluntad supone en los demás el deber de respetarla porque de otro modo no sería libre. Faltar a ese deber, es infringir el orden, la ley de la naturaleza. Las leyes civiles vienen á suplir lo limitado de la inteligencia del hombre, declarando las ocasiones y las circunstancias en que estos derechos y deberes individuales y correlativos existen. [En la aplicación de las leyes civiles] la intervención del Monarca se reduce únicamente al nombramiento de los magistrados y jueces, puesto que no está en su mano ni removerlos, ni intervenir en sus fallos, ni revocarlos. Esta restricción, indispensable para no poner en manos de la arbitrariedad los derechos de los hombres, y sobre todo su libertad y su vida, convierte á la justicia civil en un verdadero poder político independiente del legislativo y del ejecutivo" ". En la misma línea, autores progresistas como GÓMEZ DE LA SERNA y MONTALBÁN insistían en que al derecho subjetivo son consubstanciales: (i) la acción, que es "la facultad de perseguir en juicio nuestros derechos"; y (ii) las reglas procesales destinadas a asegurar la igualdad de armas: "las leyes que establecen los procedimientos judiciales" son "el complemento de las que fijan los derechos de los ciudadanos [...]. Sin un sistema de actuaciones preciso y riguroso [...] la administración de justicia sería arbitraria y desigual, y por falta de medios de aplicación las leyes civiles [...] vendrían a ser letra muerta"; la protección de los derechos exige dentro de "nuestra organización política actual", un "orden judi-

vom Standpunkte des heutigen Rechts, Julius Buddeus, Düsseldorf, 1856. Pese a su positivismo e historicismo declarados, SAVIGNY y, en general, toda la Ciencia de la Pandectas, acabaron edificando un Derecho privado criptoiusnaturalista, basado en la libertad como fundamento del Estado y el Derecho. Sobre la prioridad atribuida al derecho subjetivo frente al Derecho objetivo en la Escuela de Derecho Natural, Giorgio PINO, "Diritti soggettivi”, capítulo 4, en A. SCHIAVELLO y V. VILLA (dir.), Filosofia del diritto. Introduzione critica al pensiero giuridico e al diritto positivo, Giappichelli, Torino, 2013. Sobre todo ello, MEDINA ALCOZ (2016: 53-59).

8 De acuerdo con el indicado proyecto: "La ley es la voluntad de todos los españoles de ambos hemisferios, expresada por medio de sus legítimos representantes, y corroborada por la sanción del Rey con arreglo á la Constitución" (art. 1); "El objeto de la ley es la distribución de derechos y obligaciones" (art. 4); "Todo derecho da acción para reclamar su ejercicio ante la Autoridad competente por los medios y formas que dispone la ley" (art. 35); "Los derechos y las obligaciones entre los individuos que nacen de sus recíprocos convenios, ó de otros títulos aprobados por la ley, se reclaman ante la autoridad judicial" (art. 274); esta "tiene por objeto la aplicación de la ley en los asuntos litigiosos" (art. 266) y se corresponde con "el Tribunal ó Juez que designó la ley con anterioridad" (art. 275). El fin de la "Administración General del Estado en el ramo judicial" (Parte segunda, libro segundo) es "hacer efectivo los derechos y obligaciones" de los espańoles (Parte primera).

9 Cristóbal BORDIÚ Y GÓNGORA, Del Consejo Real como elemento del Gobierno constitucional, Imprenta de la Compañía de Impresores y Libreros, Madrid, 1846, pp. 20-22. 
cial" independiente "por las restricciones que respecto de él tiene el ejecutivo, que ni puede destituir à los magistrados, ni intervenir en los juicios" ${ }^{10}$.

El individualismo cultivado por la Escuela de Derecho natural y decantado a la teoría general del Derecho conducía muy directamente a consagrar el Derecho relativo a la administración como un sistema de poderes de policía y, a la vez, como un sistema de derechos subjetivos del administrado. Permitía justificar tanto la idea de potestad como coacción exclusivamente destinada a salvaguardar libertades individuales, como la idea de derecho subjetivo. Los principios de correlatividad y protección plena encerrados en la noción de derecho subjetivo eran derivaciones lógicas de la premisa liberal que en modo alguno quedaban circunscritas a las relaciones entre particulares. Antes bien, los textos revolucionarios y constitucionales proclamaron la centralidad de los derechos como instrumento de defensa de la libertad individual frente al Estado. No había, en definitiva, dificultad técnica alguna para que la lengua de los derechos fuera la clave de lectura de la legislación jurídico-administrativa ${ }^{11}$.

Por eso es enteramente normal que quienes se ocuparon inicialmente del naciente Estado administrativo manejasen con toda naturalidad la lengua de los derechos. Antes del derrumbamiento del Derecho civil como ordenación general, común y universal, cuando el pensamiento jurídico estaba todavía impregnado por la cosmovisión liberal, las obligaciones de la naciente administración se interpretaban, en efecto, como derechos individuales. La lengua de los derechos dominó inicialmente entre nosotros y, en general, allí donde la administración no estaba singularizada, sujetándose a los tribunales del mismo modo que los particulares. Ni siquiera la consolidación de regímenes de justicia administrativa la erradican en principio. El francés Louis CABANTOUS no decía nada original cuando insistía en que "hay derecho adquirido si el hecho o el acto contra el que se reclama ha sido realizado a despecho de una obligación legal de la Administración" ${ }^{12}$. El italiano Lodovico MORTARA señalaba en igual sentido que el ciudadano que acude a la justicia del Consejo de Estado hace valer el derecho subjetivo al correcto ejercicio de las potestades administrativas ${ }^{13}$.

En España, el profesor PELÁEZ DEL POZO, tras afirmar que los actos discrecionales no son fiscalizables, precisaba que debían serlo si "hubieren marcado las

10 Pedro GÓMEZ DE LA SERNA Y TULLY y Juan Manuel MONTALBÁN HERRANZ, Tra-

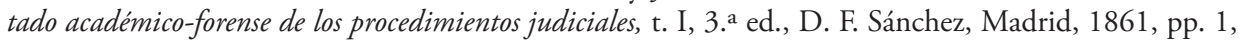
6-9 y 287.

11 Es importante resaltarlo a la vista de que la doctrina administrativista actual considera que la asociación de la obligación impuesta a la potestad administrativa a un derecho subjetivo correlativo del ciudadano perjudicado por el incumplimiento constituye un desarrollo atípico o especial que no estaba al alcance de los juristas del siglo xix. Sobre este equívoco, MEDINA ALCOZ (2016: 189-191, 243-251).

${ }^{12}$ Louis CABANTOUS, Répetitions Écrites sur le droit public et administratif, 4. ${ }^{a}$ ed., A. Maresco Ainé, Paris, 1867, p. 307. Tomo la cita de Maurice HAURIOU, "La gestión administrativa", en Obra escogida, trads. J. A. SANTAMARÍA PASTOR/S. MUNOZ MACHADO, Instituto de Estudios Administrativos, Madrid, 1976 (original de 1899), p. 162.

13 Lodovico MORTARA, "Sulla classificazione degli atti amministrativi (d'impero e di gestione)", Giurisprudenza italiana, vol. I/1, 1899, pp. 549-552. 
leyes ciertos requisitos" y "estos no se hubieren cumplido": el particular "sobre el que dichos actos obraron tenía por la ley una garantía, un derecho en los requisitos conculcados ó despreciados por dicho acto, y este derecho es el que ocasiona la vía contenciosa" ${ }^{14}$. En esta misma línea, Santos ALFARO Y LAFUENTE razonaba que "todo individuo tiene derechos administrativos porque donde hay obligaciones [de la administración] hay derechos, pues son correlativos y no podrán existir los unos sin los otros" 15 . El autor concebía el "derecho subjetivo administrativo" como la posición individual correspondiente a cualquiera de las obligaciones que el Derecho objetivo impone a la potestad administrativa, esto es, la situación que permite exigir a la administración, cuando hace "uso de sus facultades regladas", que "no se separe en lo más mínimo de la ley, el reglamento ó el contrato que le dan norma" ${ }^{16}$. En consonancia con estos planteamientos, el Consejo Real (o de Estado, a partir de 1858) interpretaba la obligación de carácter formal que la ley impone al ejercicio de los poderes de la administración como un derecho subjetivo correlativo, el "derecho a las formas" o al "trámite" (Real Decreto Sentencia de 30 de julio de 1847); doctrina trasmitida después a la unidad de fueros en favor de la jurisdicción ordinaria establecida durante el Sexenio Democrático (p. ej., SSTS de 18 de octubre de 1871 y 20 de febrero de 1872) ${ }^{17}$. La idea está registrada y desarrollada en todos los estudios relativos al contencioso-administrativo español. Por ejemplo, Manuel MALO DE MOLINA insistía en que la justicia administrativa debía proteger "el derecho que todo particular tiene para ser administrado por la autoridad competente" ${ }^{18}$.

La justicia administrativa judicializada de 1888 conservó y desarrolló estos planteamientos ${ }^{19}$. Declaró que, "aun cuando una Ley confiera al Poder ejecutivo facultades libérrimas, si para su ejercicio establece determinadas reglas, debe observarlas cuando llega el caso de aplicarlas, á menos que prefiera derogarlas antes de dictar la resolución correspondiente, y desde el momento en que la Administración debe acomodar sus actos á una Ley, Reglamento ú otro precepto, obra en el ejercicio de sus facultades regladas, y si con ellos infringe dichas reglas vulnerando un derecho reconocido por las mismas, el Tribunal tiene competencia para restablecer el estado jurídico alterado" (Sentencia de 15 de enero de 1892). Por lo mismo, el licitador que concurría a una subasta pública tenía reconocido el derecho a que el remate se adju-

14 Julián PELÁEZ DEL POZO, Tratado teórico-práctico de la organización, competencia y procedimientos en materias contencioso-administrativos, Imprenta D. B. González, Madrid, 1849, p. 25. Las cursivas son del texto original.

15 Santos ALFARO Y LAFUENTE, Jurisprudencia del Consejo de Estado sobre la procedencia de las demandas administrativas, Imprenta de la Revista de legislación á cargo de Julián Morales, Madrid, 1867, p. 11.

16 Santos ALFARO Y LAFUENTE, Tratado completo de lo contencioso-administrativo, Imprenta Nicolás González, Madrid, 1875, pp. 17-58, 247-250.

17 Andrés BETANCOR RODRÍGUEZ, El acto ejecutivo, CEPC, Madrid, 1992, pp. 235-236.

18 Manuel MALO DE MOLINA, Conferencias sobre lo contencioso-administrativo, pronunciadas en el Ateneo de Madrid en el curso de 1860 a 1861, Arcas y Sánchez, Madrid, 1861, p. 32.

$19 \mathrm{Al}$ respecto, Enrique SERRANO GUIRADO, "La justicia administrativa”, RAP, núm. 6, 1951, pp. $143-162$ (p. 155). 
dicase solo a los que hubieran llenado las condiciones fijadas por la administración (Auto de 20 de septiembre de 1889).

En realidad, el Derecho administrativo de los derechos subjetivos fue solo un espejismo, incluso en España, pese a que la legislación, la jurisprudencia y la doctrina lo configuraron formalmente así durante el siglo xix y la primera mitad del siguiente. Por más que ese Derecho fuera una derivación lógica y natural de la libertad en el plano de las ideas, su realización efectiva topaba con el interés de la burguesía y de las monarquías restauradas por erigir una administración fuerte, ampliamente capacitada para intervenir sobre la vida social. El "derecho subjetivo" alumbrado por la tradición iusnaturalista no acabó trasplantado al Derecho administrativo. La idea de libertad valió para fundar prerrogativas administrativas, pero no auténticos derechos individuales: el XIX fue el siglo de los poderes de la administración, no de los derechos subjetivos frente a ellos, ni de "originarios" anteriores al Estado (fundados en el Derecho natural) ni los "artificiales" producidos por él (fundados en la Constitución o las leyes). No podía serlo porque en realidad fue el siglo del Estado administrativo, esto es, un Estado amplio y poderoso hegemonizado por la administración pública.

\subsection{Liberalismo conservador y negación del derecho subjetivo frente a la potestad administrativa}

\subsubsection{Planteamiento general y contexto europeo}

Los derechos naturales del hombre frente al Estado desaparecieron de la cultura jurídica del siglo xIX por efecto del iuspositivismo. Lo hicieron virtualmente también los derechos constitucionales, esto es, los proclamados en Declaraciones solemnes y Constituciones. El Derecho público continental hurtó a tales documentos el carácter de norma suprema. La cuestión del derecho subjetivo era estrictamente infraconstitucional, de modo tal que la posibilidad de exigir a la administración comportamientos de hacer o no hacer con el beneficio de la protección judicial plena pasaba a depender enteramente de la ley. Pertenecía prácticamente en exclusiva al Derecho administrativo de la misma manera que la solución del problema del derecho subjetivo en las relaciones entre particulares correspondía al Derecho civil. Ya el Discurso Preliminar del proyecto de Código de 1821 lo expresó con toda claridad: "En el orden social no existen derechos ni obligaciones sino por disposición de la ley. Con ella nacen, y mueren con ella”. El político y jurista Antonio ALCALÁ GALIANO, liberal exaltado de juventud, y destacado líder del partido moderado en la madurez, fue aún más rotundo en 1843: "No reconozco yo un solo derecho en los individuos ni un solo punto en la Constitución que no pueda ser variado o suspendido por la autoridad (se entiende), 'que tiene facultad de hacer las leyes y no por otra'; "enlaza esta doctrina con la de la omnipotencia parlamentaria" ${ }^{20}$. En suma, los derechos subjeti-

20 Antonio ALCALÁ GALIANO, Lecciones de Derecho político constitucional, Boix, Madrid, 1843, pp. 410, 414. El entrecomillado en cursiva es del original. 
vos eran exclusivamente legales, existían en función de la ley, no de la constitución. Se trata de un planteamiento común a toda la cultura europea, cuyo origen se halla en la centralidad que el liberalismo continental asignaba a la ley para liquidar el viejo orden feudal y que, superado el ecuador del siglo XIX, desarrolló ampliamente la Escuela alemana de Derecho público.

El problema es que la ley, colocada en el centro del sistema político, atribuía derechos solo en las relaciones entre particulares y en las relaciones administrativas horizontales. Situados en el plano de la legalidad, los límites que debía respetar la administración revestida de imperio no podían funcionar como derechos subjetivos correlativos del ciudadano perjudicado por su incumplimiento. Lo impedía la finalidad de interés general a la que se orienta esencialmente toda norma reguladora de potestades administrativas. Frente a la obligación que deriva de la potestad el ciudadano contaba con un mero "interés" o derecho "secundario" ("imperfecto", de carácter "administrativo", "que se mezcla con el interés general"), lo que implicaba la imposibilidad de recurrir o la posibilidad de hacerlo solo ante una jurisdicción administrativa y asimétrica.

La justicia administrativa respondía a una teoría de las relaciones entre la administración y el ciudadano por completo singular. El establecimiento de un foro especial para la administración, sin las garantías de independencia y sin los remedios subjetivos propios de los procesos civiles, implicaba, por un lado, que el Estado estaba autorizado a rechazar o degradar los derechos del ciudadano frente a la administración sin sujeción a la libertad como condición preexistente de la persona; y, por otro, que consideraba efectivamente que la autoridad y el interés general están muy por encima del individuo y la libertad personal. La normalización de la desigualdad de armas y la concepción del proceso como mecanismo de protección del orden jurídico (o de posiciones subjetivas de segunda categoría) eran la expresión de un Derecho administrativo "desiusnaturalizado" y "desconstitucionalizado" que sobreprotege a la administración en cuanto encarnación del interés general, de la sociedad o del Estado ${ }^{21}$. Evidenciaba en suma que el Estado disponía de un poder ilimitado (esto es, sin límites de Derecho natural o constitucional) para decidir si, y hasta qué punto, los ciudadanos han de contar con derechos subjetivos.

El "derecho subjetivo" sintetizaba las ideas de individuo y libertad. Se concretaba en las exigencias de correlatividad y protección judicial plena en un proceso paritario. Frente a él, aflora el derecho "secundario" ("imperfecto" o "administrativo") o "interés legítimo" como concepto basilar del Derecho administrativo continental, una síntesis de las ideas de sociedad y autoridad que retrataba la posición de inferioridad del ciudadano enfrentado a la administración. Significaba la negación del derecho subjetivo como posición correlativa a las obligaciones de la administración en "estado de mando" y, con ello, la de la protección judicial plena. Servía en suma para garanti-

21 Las expresiones entrecomilladas, en Gonzalo MAESTRO BUELGA, "Los derechos públicos subjetivos en la historia del constitucionalismo español", Revista de Derecho Político, núm. 41, 1996, pp. 119-175 (pp. 131-132). 
zar inmunidad jurisdiccional a la administración o edificar una justicia administrativa especial, menos garantista que la ordinaria o civil. Corresponde abordar con algún detenimiento algunos ejemplos comparados a fin de contextualizar el caso español.

a) Durante la segunda mitad del siglo xIX, el Consejo de Estado francés fue modelando el recurso por excès de pouvoir no como un proceso entre partes destinado a proteger derechos subjetivos, sino como un proceso al acto de imperio destinado a tutelar el Derecho objetivo del que solo podía resultar la anulación. La jurisdicción encargada de controlar la puissance publique era pues una jurisdicción objetiva (o de Derecho objetivo) de carácter meramente revisor en oposición a la jurisdicción administrativa subjetiva (o de derecho subjetivo) de carácter pleno, encargada de enjuiciar los conflictos que surgían en relaciones horizontales entre el ciudadano y la administración, cuando esta llevaba a cabo actuaciones de pura gestión (p. ej., contratación, daños extracontractuales). Ciertamente, a través del recurso por exceso de poder el particular estaba autorizado a impugnar actos de autoridad, pero se entendía que actuaba cual ministerio fiscal, no como titular de derechos. Es verdad que la impugnación era admisible solo si la resolución combatida afectaba o perjudicaba personalmente al recurrente, pero ello expresaba la ambición de evitar la acumulación de asuntos, no de proteger derechos. Se afirmaba así el "interés" como simple "requisito de seriedad" de un recurso que ponía en marcha el autocontrol administrativo para garantizar la legalidad objetiva exclusivamente. Un interés que en ningún caso podía identificarse con una posición jurídico-material protegida por el ordenamiento jurídico, esto es, con un derecho ${ }^{22}$. La afirmación del interés como condición procesal de legitimación presuponía la negación del derecho subjetivo (frente a la puissance publique) y, con ello, la de la plena protección jurisdiccional (en el recurso por excès de pouvoir). En suma, el recurso por exceso de poder era un mecanismo destinado a salvaguardar el interés general protegido por la norma jurídico-administrativa incumplida mediante la expulsión del acto administrativo ilegal, no a tutelar el interés individual del ciudadano. Se consideraba que este no está contemplado en la norma ${ }^{23}$.

b) En el entorno germánico, Rudolf von GNEIST afirmaba que las normas que regulan el "ejercicio del poder" son "Derecho objetivo" al servicio del "bien público" de modo que el "carácter jurídico" del "interés" que en ellas tiene el particular no es el propio del "derecho individual", único merecedor de "tutela jurídica". Ese interés es un "derecho secundario" que el súbdito puede hacer valer cual ministerio fiscal en el proceso penal. El autor alumbraba así una teoría de las situaciones activas del administrado penetrada por la afirmada prevalencia del interés general que hallaba traducción procesal en su propuesta de una jurisdicción administrativa objetiva: el control a

22 Edouard LAFERRIÈRE elaboró el concepto de "interés" (personal, directo y legítimo) como pieza que es al contencioso objetivo de anulación lo que el derecho subjetivo es al contencioso subjetivo de plena jurisdicción: "la vigilancia de los intereses lesionados constituye la mejor salvaguardia de la legalidad". Edouard LAFERRIÈRE, Traitè de la juridiction administrative et des recours contentieux, 2 vols, reimpresión prologada por R. DRAGO, LGD, 1989 (original de1887). La teorización del concepto de interés puede leerse en el tomo primero (pp. 15-19) y, sobre todo, en el segundo (pp. 367-548)].

${ }^{23}$ Con más detalle: MEDINA ALCOZ (2016: 101-108). 
la administración debe realizarse siempre "en interés del Staatsordnung" de modo que la Petition um den Rechtsweg permita al ciudadano obtener protección solo indirecta frente a la acción arbitraria o parcial de la administración ${ }^{24}$. La primera figura del Derecho administrativo alemán, Otto MAYER, desarrolló esta tesis ${ }^{25}$. También se ajustaron a ella los regímenes contencioso-administrativos de los Estados del norte de Alemania. En particular, el Tribunal Superior Administrativo de Prusia adoptó el enfoque objetivo. Concebía el contencioso-administrativo como proceso destinado a la protección no de los derechos individuales del recurrente, sino de los intereses públicos que persiguen las normas reguladoras del poder administrativo ${ }^{26}$. El fondo de este planteamiento subsistía en los Länder que apostaron por una jurisdicción subjetiva destinada a proteger derechos subjetivos. El ciudadano seguía sin obtener protección judicial plena si la norma que pretendía hacer valer estaba orientada al interés general. Más precisamente, si la administración infringía una norma que perseguía objetivos colectivos, el perjudicado por el incumplimiento no tenía acceso a jurisdicción alguna, ni siquiera un recurso de Derecho objetivo. Se entendía que tal ciudadano no atesoraba un derecho subjetivo, sino un mero interés de hecho carente en cuanto tal de protección judicial. Tal es la doctrina esbozada embrionariamente por IHERING (en el marco de su concepto de derecho como interés privado jurídicamente protegido) ${ }^{27}$ y formulada por Georg JELLINEK (como teoría del derecho público subjetivo: subjektives öffentliches Recht) ${ }^{28}$.

c) En Italia, se instituye finalmente un régimen de justicia administrativa (1889) similar al contencioso-administrativo francés y español. La administración, en sus relaciones horizontales con los ciudadanos, podía vulnerar derechos subjetivos. Las controversias consecuentes habían de corresponder a la justicia ordinaria, beneficiándose, por tanto, de la independencia judicial y la protección plena. En cambio, en las relaciones verticales, la administración solo podía vulnerar una posición subjetiva de segunda categoría, penetrada por el interés general (interés legítimo). En tal caso, la controversia se sustraía al sistema común de jueces y magistrados, pasando al Consejo de Estado. Este órgano controlaba la legalidad de los actos administrativos mediante un único instrumento: la anulación del acto administrativo ilegal. La

${ }_{24}$ Rudolf von GNEIST, Lo Stato secondo il diritto ossia la giustizia nell'amministrazione politica, traducción de I. ARTOM, Zanichelli, Bologna, 1884 (original de 1879), en especial p. 214. El autor defendió esta postura también en la reunión de la Asociación de juristas alemanes de 1875 [Bernhard WEGENER ("Subjective Public Rights-Historical Roots versus European and Democratic Challenges", en H. PÜNDER y Ch. WALDHOFF (ed.), Debates in German Public Law, Hart Publishing, Oxford, 2014, pp. 219-238 (p. 226)].

25 Otto MAYER, Derecho administrativo alemán, t. I (Parte general), Depalma, Buenos Aires, 1982 (original de 1895), pp. 218-220.

26 Más detalles en Santiago GONZÁLEZ-VARAS IBÁÑEZ, La jurisdicción contencioso-administrativa en Alemania, Civitas, Madrid, 1993, pp. 75 ss.

27 Rudolf von IHERING, El espiritu del Derecho romano en las diversas fases de su desarrollo, Comares, Granada, 1998 (original de 1852-1865), pp. 1025-1051, especialmente pp. 1040-1043.

${ }_{28}$ Georg JELLINEK, Sistema dei diritti pubblici subbiettivi, traducción italiana de la 2.a ed. (1. ${ }^{\mathrm{a}} \mathrm{ed}$. de 1892), Libraria, Milano, 1912 (original de 1905). 
sobreprotección del interés general (con la consiguiente ruptura de la igualdad de armas característica del Derecho procesal civil) se apreciaba también en las restricciones a la revisión de los hechos apreciados por la administración activa. La justicia administrativa se presentaba como una justicia distinta y separada de la jurisdicción ordinaria con garantías de independencia y facultades tutelares más reducidas ${ }^{29}$. Tal planteamiento fue desarrollado a partir del dato legal por Oreste RANELLETTI ${ }^{30}$; se refería al interés legítimo como derecho "debilitado" (affievolito) ${ }^{31}$.

Los sistemas jurídicos deben juzgarse no solo en función de su marco normativo, sino también de los resultados obtenidos con él. Bajo la óptica de las garantías, lo decisivo a la postre son, no las premisas ideológicas adoptadas, tampoco las normas, ni siquiera las palabras, sino los remedios efectivamente reconocidos a través de ellas ${ }^{32}$. Como es sabido, el Conseil d'État elaboró una jurisprudencia creativa y audaz. Funcionó en la práctica como un órgano con criterio independiente y experto. La solución "heterodoxa" de una justicia administrativa demostró la posibilidad práctica de una administración sometida a la ley y, a la vez, enormemente capacitada para conformar la vida social ${ }^{33}$. El Derecho inglés era más "ortodoxo" y fiel a la idea liberal subyacente a los conceptos de derecho subjetivo y separación de poderes. Frente a los special powers de las autoridades y agencias gubernamentales el ciudadano podía oponer rights. La administración estaba sometida a los ordinary common law principles que gobiernan las relaciones de los particulares y a su mismo foro. Sin embargo, paradójicamente, realizaba en la práctica menos garantías que un régime administratif que negaba el derecho individual frente a la puissance publique y destinaba la justicia administrativa a la realización de los fines públicos del Derecho objetivo. El ciudadano inglés, cuando no topaba con bastiones de inmunidad de la corona directamente asegurados por la ley, tropezaba con un poder judicial extremadamente deferente hacia el Gobierno; limitaba su control a la competencia (ultra vires) y al procedimiento $^{34}$.

29 Ampliamente, destacando la decisiva influencia de las tesis de von GNEIST en la creación de la justicia administrativa italiana: Bernardo SORDI, Giustizia e amministrazione nell'Italia liberale. La formazione della nozione di interesse legittimo, Giuffrè, Milano, 1985, pp. 23-214.

30 Oreste RANELLETTI, A proposito di una questione di competenza della IV Sezione del Consiglio di Stato, Avezzano, Angelini, 1892, pp. 3, 75-76.

31 Al respecto, ampliamente, SORDI (1985). Compararando sistemas jurídicos, MEDINA ALCOZ (2016: 115-123).

32 En este sentido, por ejemplo, Sebastián MARTÍN-RETORTILLO BAQUER, Alejandro Oliván: Reflexiones sobre su vida y su obra, Civitas, Madrid, 1997, pp. 86-87; Aldo TRAVI, Lezioni di giustizia amministrativa, Giappichelli, Torino, 2012, p. 53.

33 Juan Alfonso SANTAMARÍA PASTOR, Sobre la génesis del Derecho administrativo español en el Siglo XIX (1812-1845), Iustel, Madrid, 2006 (original de 1972), p. 68.

34 El propio DICEY destacaba positivamente que el Consejo de Estado francés había edificado "nuevos remedios para una variedad de abusos"; abusos que la ordinary law of the land difícilmente podría corregir - touch - en Inglaterra. No obstante, seguía opinando que el droit administratif constituía un sistema primitivo imbuido de las concepciones del Estado absoluto: Albert Venn DICEY, Introduction to the Study of the Law of the Constitution, reimpresion de la 8. a ed., coords. Roger E. Michener, Liberty Fund, Indianapolis, 1982 (original de 1915), p. 215; y Comparative Constitutio- 
Ahora bien, el caudal liberador que abrieron las decisiones del Conseil d'État tampoco debe ocultar el profundo significado del concepto de "interés". No cabe presentar sin más un recurso objetivo (sin posibilidad de proporcionar protección plena porque las obligaciones de la administración no son los derechos correlativos del ciudadano que padece su incumplimiento) como instrumento técnico al servicio de un sistema de garantías subjetivas solo porque a través de él Francia alcanzara mayores cotas tutelares que los ordenamientos que, o bien llevaban más lejos sus mismos presupuestos autoritarios (Alemania, España), o bien no realizaban verdaderamente sus postulados liberales (Inglaterra). Una cosa es valorar un sistema jurídico a través de sus resultados, sin fijarse solo en los conceptos -ello es absolutamente necesario-, y otra escudarse en esos resultados para dejar de valorar los conceptos en sí, sin aquilatar ni evaluar sus potencialidades. Esto último parece poco recomendable: cuando un ordenamiento jurídico importaba de Francia la justicia administrativa y el concepto de interés, traía consigo una visión autoritaria del Derecho objetivo y de las situaciones subjetivas, pero no, necesariamente, las garantías que desarrollaba el Conseil d'État. Por lo demás, no puede perderse de vista que el Derecho administrativo en Francia: (i) fue construido sobre las ruinas del Antiguo Régimen para servir al Imperio; (ii) hasta la Tercera República (1870) tuvo un claro componente "despótico y autoritario", como Derecho ex parte principis y "aparato de obediencia"; y (iii), al configurar el recurso por exceso de poder como recurso de Derecho objetivo, impuso una serie muy relevante de trabas y limitaciones a la protección judicial del ciudadano que, silenciadas doctrinalmente durante largo tiempo, han estado vigentes hasta bien entrado el siglo $\mathrm{xx}^{35}$.

nalism, ed. J. W. F. ALLISON, Oxford Universtiy Press, Oxford, 2013 (original de 1895-1909), pp. 313-314. Sobre la discrepancia entre el Derecho inglés y francés en el plano de la realidad, así como en el de los tipos ideales construidos por DICEY y HAURIOU: Sabino CASSESE, Derecho administrativo: Historia y futuro, Global Law Press, Sevilla, 2014, pp. 47-69, 143-210; y Martin LOUGHLIN, Foundations of Public Law, Oxford University Press, Oxford, 2012, pp. 440-445. Entre nosotros, revalorizando la visión de DICEY del Droit administratif como un Derecho de corte autoritario, Bartolomé CLAVERO SALVADOR, Happy Constitution. Cultura y lengua constitucionales, Trotta, Madrid, 1997, pp. 181-208.

35 En este sentido, CASSESE (2014: 37, 44-46, 403-404). También Eduardo GARCÍA DE ENTERRÍA ["Sobre los derechos públicos subjetivos", REDA, núm. 6, 1975, pp. 427-448], pese a que llegó a considerar el recurso por exceso de poder "una de las más grandes construcciones de la Historia del Derecho de todos los tiempos" a la vista de las garantías individuales producidas gracias a él. En realidad, se opuso a la configuración objetiva y revisora del contencioso francés, haciéndose eco de una tímida corriente crítica en la doctrina gala (KORNPROBST, LALIGANT). Después subrayó las importantes trabas que esa configuración producía todavía a finales del siglo xx; trabas que, según afirmaba, habían permanecido en buena medida ocultas como consecuencia de la autocomplacencia de la doctrina francesa mayoritaria: GARCÍA DE ENTERRÍA, Las Transformaciones de la Justicia Administrativa: De excepción singular a la plenitud jurisdiccional. ¿Un cambio de paradigma?., Thomson/Civitas, Cizur Menor, 2007, pp. 79-118. 


\subsubsection{El derecho subjetivo de carácter administrativo como derecho "secundario" o "imperfecto"}

En España, el profesor PELÁEZ DEL POZO formuló muy pronto y brillantemente la teoría de la doble personalidad estatal. El Estado tendría una personalidad "civil", con consecuente sujeción al Derecho civil y a los tribunales ordinarios, cuando actúa en pie de igualdad con los particulares; y una personalidad "administrativa" con consecuente sujeción al Derecho administrativo y al contencioso-administrativo, cuando persigue el interés general y hace valer su superioridad ${ }^{36}$. La generalidad de los autores adoptó este planteamiento, diferenciando entre el Estado-persona jurídica y Estado-poder o Estado-autoridad ${ }^{37}$. También la jurisprudencia administrativa ${ }^{38}$.

36 PELÁEZ DEL POZO (1849: 13-16): "El Estado ha sido y puede siempre con razón ser considerado como una persona; pero persona moral colectiva [...]. Esta persona moral constituida por lo que se llama estado se diferencia de la persona individuo; primero y principalmente en que la idea de esta persona tiene un objeto individual solo, único, y es el hombre en su naturaleza individual; mientras que el objeto de aquella es un ente colectivo; la sociedad, la reunión de varios individuos y lo inmediato en ella, no son estos individuos sino las relaciones de su reunión ó sociedad. La persona Estado así considerada y la persona individuo tienen fines distintos ó diferentes que cumplir [...]. Esto no obstante, el Estado algunas veces se individualiza, se hace, por así decirlo, de la misma condición que el individuo, á manera de una corporación cualquiera, de una sociedad de las que reconoce como individuos de derecho. Bajo este concepto, el Estado puede poseer y contratar como lo verifica el individuo, quedando sujeto al derecho común o mas propiamente al civil [...]. Al poseer y contratar como lo verifica el individuo y para los mismos fines que éste, tiene que emplear los mismos medios que el individuo emplea y sujetarse á las mismas condiciones [...]. Mas no siempre el Estado se individualiza: su personalidad no en todos los casos se limita á poseer y contratar como los individuos, sino que dirigiéndose á otros fines, cumpliendo misión distinta, gobierna ó administrativa [...]; elemento que por su naturaleza no cabe de lleno en la esfera del derecho civil [...]. En la administración pura domina el carácter de acción, lo que los romanos llamaban potestad, imperio mero, ó simple autoridad, manifestándose bajo la forma de acción ó de mando, ya espida órdenes y reglamentos, ya se limite á llevar á debida ejecución las leyes ó reglamentos que la completan"; "la esencia, pues, de lo propiamente llamado contencioso-administrativo estriba en el carácter con que la personalidad del Estado se presenta en contestación de derechos con el individuo que considera el fuero civil. Si esa personalidad es civil, las contiendas que provoque pertenecen à lo contencioso-jurídico, y á los tribunales ordinarios; si la personalidad es gobernante ó administrativa, las contiendas que con este carácter suscite constituyen lo contencioso-administrativo, y es el juez competente en ellas la misma administración ó sus delegados".

37 José DÍAZ UFANO Y NEGRILLO, Tratado teórico-práctico de materias contencioso-administrativas en la peninsula y ultramar, M. Minuesa, Madrid, 1866, pp. 58-61; ALFARO Y LAFUENTE (1875: 17-58); id., Lo contencioso-administrativo. Su materia, sus tribunales, sus procedimientos, Librería universal de Córdoba y Compañía, Madrid, 1881, pp. 101-192; José GALLOSTRA Y FRAU, Lo contencioso-administrativo, Imprenta y fundición Manuel Tello, Madrid, 1881, pp. 8-12; Fermín ABELLA Y BLAVE, Manual teórico-práctico de lo contencioso-administrativo y del procedimiento especial en los asuntos de hacienda, El consultor de los ayuntamientos y de los juzgados municipales, Madrid, 1882, pp. 14-17; Antonio María FABIÉ ESCUDERO, Comentario de la Ley para el ejercicio de la jurisdicción contencioso-administrativa, Imprenta de la Revista de Legislación, Madrid, 1889, pp. 68-70; José María CABALLERO Y MONTES, Lo contencioso-administrativo, t. I, Escar, Zaragoza, 1902, pp. 11-12.

38 El profesor GUASP, tras analizar la doctrina y la jurisprudencia administrativas, concluyó que el dualismo Estado-poder y Estado-persona jurídica dominaba en ellas como criterio esencial para distinguir el Derecho administrativo del Derecho civil, así como para deslindar las competencias entre las jurisdicciones contenciosa y ordinaria: Jaime GUASP DELGADO, "El 'derecho de carácter adminis- 
Insistía en que el Estado a veces "desciende de la altura en que se encuentra colocado sobre los ciudadanos, se nivela con ellos y participa de sus mismos derechos y obligaciones; es, en una palabra, persona jurídica"; ejercita así "derechos civiles" cuando "adquiere, enajena, cede, arrienda o reclama bienes que le pertenecen como persona jurídica". Pero se sustrae por completo a esa personalidad, al Derecho civil y al fuero común "cuando usa libremente de la plenitud de su autoridad, sin otro correctivo que la responsabilidad que sus mandatarios contraen ante las Cortes y la opinión pública, cuando dicta reglamentos para la ejecución de las leyes, cuando declara la utilidad pública de una obra, o cuando nombra funcionarios de cierta clase"; también cuando "al administrar procede aplicando prescripciones legales o reglamentarias, o sujetándose a cláusulas pactadas por él mismo con los particulares" ${ }^{39}$.

Ciertamente, la justicia administrativa de 1845 tenía atribuido el conocimiento de asuntos de naturaleza "civil" en el sentido expuesto, caracterizados por la relación de igualdad de las partes (contratos de obras y servicios públicos, ventas de bienes nacionales ligadas a las desamortizaciones, algunas cuestiones de minas). No obstante, estas atribuciones se interpretaban como "casos de excepción que no relajan el principio general de que las cuestiones que nacen del derecho civil y se ventilan entre los particulares sin mezcla de intereses públicos, son de la competencia del poder judicial" ${ }^{40}$. En suma, no desmentían la configuración del contencioso-administrativo como jurisdicción especial de la administración en estado de mando.

Sobre esta base, los autores y el Consejo Real (o de Estado) elaboraron la distinción entre el derecho subjetivo de carácter "civil" y el derecho subjetivo de carácter "administrativo", a la postre plasmada en la Ley de la jurisdicción contencioso-administrativa de 1888. El primero, de acuerdo con su formulación legal, era el atribuido al ciudadano frente a otro particular o frente al Estado "en cuanto persona civil" situada "en relación de igualdad con él” ${ }^{41}$; su protección correspondía a la jurisdicción ordinaria (art. 4.2) con solo algunas excepciones, heredadas de la justicia administrativa originaria (p. ej., las cuestiones referentes al cumplimiento, inteligencia, rescisión y efectos de los contratos celebrados por la administración: art. 5) ${ }^{42}$. El segundo era

trativo' como fundamento del recurso de contencioso", Revista de la Facultad de Derecho de Madrid, núm. 2, 1940, p. 18.

39 Tomo la cita de GALLOSTRA Y FRAU (1881: 8-9), quien consigna "la doctrina que hace algunos años sentó nuestro consejo de Estado en uno de sus más luminosos informes”. Menciona también esta decisión ABELLA Y BLAVE (1882: 14).

${ }^{40}$ DÍAZ UFANO Y NEGRILLO (1866: 61-62). En el mismo sentido, por ejemplo, ALFARO Y LAFUENTE (1867: 18-19) y FABIÉ ESCUDERO (1889: 68-69).

${ }^{41}$ Esta definición puede leerse en el discurso de Vicente SANTAMARÍA DE PAREDES ante el Congreso (Diario de Sesiones núm. 11, de 14 de diciembre de 1887, pp. 221-223), reproducido en Luis MARTÍN REBOLLO, El proceso de elaboración de la Ley de lo contencioso-administrativo de 13 de septiembre de 1888, Instituto de Estudios Administrativos, Madrid, 1975, pp. 515-542, de donde se toma la cita (p. 519).

${ }^{42}$ Artículo 4.2 de la Ley de la jurisdicción contencioso-administrativa de 1888: "Se considerarán de índole civil y de la competencia de la jurisdicción ordinaria las cuestiones en que el derecho vulnerado sea de carácter civil, y también aquellas que emanen de actos en que la Administración haya obrado 
la posición correlativa a las condiciones normativas impuestas a las "potestades" de la administración (arts. 1, 2 y 4.1 ${ }^{\circ}{ }^{43}$; podía hacerse valer en el contencioso-administrativo. La ponencia XI del Congreso jurídico español de 1886, enunciando un criterio tradicional, señalaba que el contencioso-administrativo debía reparar la violación del "derecho subjetivo administrativo"; violación que se produce cuando la "Administración, en uso de su potestad establecida por las leyes, infringe un derecho particular nacido de la regla administrativa que debe servirle de norma, ley, reglamento o contrato" " ${ }^{4}$. El principal artífice del sistema, Vicente Santamaría de Paredes, definía igualmente la lesión del "derecho de carácter administrativo" como la infracción "en perjuicio del particular" de la "ley o reglamento" que fija "ciertas condiciones para el ejercicio de la potestad administrativa" ${ }^{45}$. El derecho venía a ser una noción sinónima de regla o norma jurídica de carácter administrativo, opuesta a regla o norma de Derecho civil ${ }^{46}$. Debía entenderse vulnerado siempre que su incumplimiento efectivo hubiera perjudicado al recurrente.

De modo que el ciudadano podía oponer posiciones casi homónimas en el proceso civil y en el contencioso-administrativo, pero la superioridad del interés general justificaba que fueran esencialmente distintas porque unas estaban mucho menos protegidas que otras. El derecho de carácter administrativo careció siempre de las garantías de imparcialidad, independencia, profesionalidad y tutela características del derecho de carácter civil, incluso después de la judicialización parcial del contencioso-administrativo promovida a finales del siglo xIX. Además de mayores dependencias respecto de la administración activa y la eventual integración de vocales no profesionales en los tribunales administrativos inferiores (profesores de instituto y de escuelas de comercio sin estudios de jurisprudencia), cabe destacar los siguientes elementos:

a) El contencioso-administrativo quedó configurado como una segunda instancia o recurso de casación contra resoluciones administrativas definitivas, necesariamente precedido de una vía gubernativa y enteramente condicionado por lo probado, alegado y decidido dentro de ella. Ciertamente, las Leyes de 1845 regulaban el proceso de modo muy similar a los enjuiciamientos civiles: se iniciaba con demanda del par-

como persona jurídica, ó sea como sujeto de derechos y obligaciones". No obstante, de acuerdo con el art. 5: "Continuarán, sin embargo, atribuidas á la jurisdicción contencioso-administrativo las cuestiones referentes al cumplimiento, inteligencia, rescisión y efectos de los contratos celebrados por la administración central, provincial y municipal para obras y servicios públicos de toda especie".

43 Tales preceptos establecían que los "particulares" podían interponer el "recurso contenciosoadministrativo" en defensa de su "derecho de carácter administrativo" contra resoluciones administrativas adoptadas en ejercicio de "facultades regladas", excluyendo las cuestiones referentes a la "potestad discrecional".

${ }^{44}$ La indicada ponencia se halla recogida íntegramente en MARTÍN REBOLLO (1975: 578).

45 Vicente SANTAMARÍA DE PAREDES, Diario de Sesiones núm. 11, de 14 de diciembre de 1887, en MARTÍN REBOLLO (1975: 520). En parecidos términos, SANTAMARÍA DE PAREDES, Curso de Derecho administrativo, 8a ed., Imprenta española, Madrid, 1914, pp. 66-69, 749-762.

46 José Ramón PARADA VÁZQUEZ, "Privilegio de decisión ejecutoria y proceso contencioso", RAP, núm. 55, 1968, pp. 65-112 (p. 104). 
ticular sin que tuviera que versar imperiosamente sobre decisiones formalizadas, sin necesidad de recurso administrativo previo, sin sujeción a plazos de interposición y sin limitación de los medios de prueba. Sin embargo, la jurisprudencia pronto exigió el acto administrativo como condición de admisibilidad de la demanda, así como la interposición del recurso dentro de breves plazos, haciendo girar las alegaciones y pruebas en torno a lo previamente decidido y demostrado en la vía administrativa: "el procedimiento contencioso-administrativo, más que un verdadero juicio, es la revisión de una acto administrativo" ${ }^{47}$; "la vía contenciosa no puede tener cabida sin que preceda una providencia gubernativa que, causando estado, ofenda o lastime el derecho de los particulares" (Real Decreto Sentencia de 8 de agosto de 1858); "la vía contenciosa no tiene otro carácter que la revisión o el examen de aquella providencia" (Real Decreto Sentencia de 10 de junio de 1868). El régimen de 1888 recogió estos criterios. Explicitó, en particular, la exigencia de la resolución administrativa definitiva como requisito para admitir el recurso contencioso-administrativo (art. $1.1^{\circ}$ de la Ley) y la regla general de que los hechos relevantes en el proceso son solo los apreciados por la propia administración en el expediente gubernativo (art. 327 del Real Decreto de 29 de diciembre de 1889) ${ }^{48}$.

b) La justicia administrativa preservó en todo momento relevantes espacios de inmunidad de la administración sin derechos o con derechos débilmente protegidos: entre ellos, la potestad reglamentaria (los reglamentos ilegales no podían ser objeto de impugnación) ${ }^{49}$, la ejecución de sentencias firmes (que correspondía a la propia administración) y la discrecionalidad administrativa. Ciertamente, la tradicional in-

47 Antonio ALCÁNTARA PÉREZ y Juan MORALES SERRANO, Tratado de las competencias y de la autorización para procesar a los empleados públicos, t. I, Imprenta de J. E. Morete, 1866, p. XXVIII.

48 Se ha debatido en torno al preciso momento en que quedó establecido el carácter revisor de la justicia administrativa. De acuerdo con el profesor NIETO, estaba ya implícito en las leyes de 1845 de creación de la justicia administrativa: Alejandro NIETO GARCÍA, "Sobre la tesis de Parada en relación con los orígenes de lo contencioso-administrativo", $R A P$, núm. 57, 1968, pp. 9-34; id., "Del Consejo Real como elemento del Gobierno constitucional", RAP, núm. 84, 1977, pp. 537-552. Según PARADA VÁZQUEZ [(1968: 65-112) y "Réplica a Nieto sobre el privilegio de decisión ejecutoria y el sistema contencioso-administrativo", $R A P$, núm. 59, 1969, pp. 41-70] habría sido más bien una elaboración jurisprudencial temprana. Investigaciones sucesivas han reforzado esta última tesis, sin perjuicio de reconocer que el acto previo como condición de admisibilidad se hallaba ya en el Reglamento del Consejo de Real de 30 de diciembre de 1846 (arts. 1.2 $2^{\circ}$ y 51) y que pronto acabó convertido en patrón de la sentencia, sin posibilidad de plantear en la vía contenciosa lo no pedido ni resuelto en la gubernativa: Juan Alfonso SANTAMARÍA PASTOR, "Sobre el origen y evolución de la reclamación administrativa previa”, RAP, núm. 77, 1975, pp. 81-180; BETANCOR RODRÍGUEZ (1992: 117-196); Juan Ramón FERNÁNDEZ TORRES, La formación histórica de la jurisdicción contencioso-administrativa (1845-1868), Civitas, Madrid, 1998, pp. 607-642.

49 La jurisprudencia contencioso-administrativa excluyó siempre el recurso directo y limitó enormemente el alcance del indirecto, inmediatamente dirigido a los actos de aplicación; recurso que había previsto explícitamente la Ley de la jurisdicción contencioso-administrativa de 1888 (art. 3). Solo la Constitución de 1869 y la Ley provisional sobre organización del poder judicial de 15 de septiembre de 1870 abrieron algún resquicio al control judicial en este ámbito al autorizar la inaplicación judicial del reglamento ilegal. Sobre ello, ampliamente: Gabriel DOMÉNECH PASCUAL, La invalidez de los reglamentos, Tirant lo Blanch, Valencia, 2002, pp. 56-65. 
fiscalizabilidad de la discrecionalidad, reafirmada en la Ley de la jurisdicción contencioso-administrativa de 1888 (arts. $1.2^{\circ}$ y $4.1^{\circ}$ ), no impedía por sí el control de los requisitos legales que enmarcaban su ejercicio, concebidos como derechos subjetivos de carácter administrativo. Sin embargo, durante muchos ańos la justicia administrativa controló solo la aplicación de las reglas de forma o procedimiento, sin tomar en consideración otros principios jurídicos, como la prohibición del abuso de poder. A su vez, la catalogación de un acto como discrecional operó, al menos hasta principios del siglo $\mathrm{xx}$, como motivo de inadmisión liminar, sin que, en consecuencia, pudiera trabarse un debate de fondo en torno a la eventual concurrencia de límites jurídicos y su posible inobservancia. Por lo demás, las resoluciones administrativas adoptadas en determinadas materias (orden público, salud, defensa del territorio y "concesiones de toda especie") se reputaban discrecionales por naturaleza con entera independencia del grado efectivo de programación normativa (arts. 4 y 6 del Real Decreto de 29 de diciembre de 1890).

La literatura jurídica subrayó elocuentemente desde el principio las diferencias entre los derechos de carácter civil, que podían hacerse valer con plenitud de tutela ante la jurisdicción, y los derechos de carácter administrativo, cuya protección quedaba atribuida al contencioso-administrativo. De acuerdo con BORDIÚ Y GONGORA, los derechos administrativos son las posiciones atribuidas al hombre no en cuanto "ser individual", sino en cuanto "ser social", obligado a "contribuir al buen gobierno"; la "conveniencia pública" requiere "disminuir las garantías" propias de los "juicios civiles" y que "contra los actos de imperio de la administración no puedan alegarse derechos propiamente dichos"; "la administración está, pues, en el caso de cumplir su misión por sí misma, sin que el poder judicial entorpezca su marcha só pretesto de que huella derechos individuales" ${ }^{50}$. Según MALO DE MOLINA, los derechos administrativos son los "que se mezclan con el interés general que defiende la Administración", que solo pueden dar lugar a una "controversia cuasi judicial", esto es, al "contencioso-administrativo" 51 . También para GALLOSTRA: "la administración tiene que preocuparse del bienestar del individuo, pero armonizándolo con el interés de la colectividad; y así cuando el interés individual se presenta en pugna con el interés social, la Administración prefiere á éste y sacrifica á aquel, si es necesario. He aquí las diferencias. Por eso son de índole tan distinta los derechos que reconoce y ampara la Administración, de los que la Justicia ampara ó confirma" 52 . POSADA HERRERA se refirió al derecho de carácter administrativo como derecho "imperfecto" en uno de sus últimos escritos: "La noción de esta justicia [la contencioso-administrativa] es una extensión de la justicia ordinaria á derechos más imperfectos que los civiles de las personas" ${ }^{53}$.

\footnotetext{
50 BORDIÚ Y GÓNGORA (1846: 20, 23, 34, 50).

51 MALO DE MOLINA (1861: 9 y 23).

52 GALLOSTRA Y FRAU (1881:123)

53 José POSADA HERRERA, prólogo a J. GALLOSTRA Y FRAU, Lo contencioso-administrativo, Imprenta y fundición Manuel Tello, Madrid, 1881, p. XI.
} 
Avanzado el siglo xIx, GONZÁLEZ CARMONA rechazó elocuentemente la doble personalidad estatal y, con ello, la especialidad tanto del derecho subjetivo de carácter administrativo como de la jurisdicción encargada de protegerlo ${ }^{54}$. No obstante, la categoría del derecho subjetivo de carácter administrativo como fundamento de una justicia especial cristalizó en la Ley de la jurisdicción contencioso-administrativa de 1888 y siguió contando con destacados defensores, como José María CABALLERO Y MONTES ${ }^{55}$ y Jaime GUASP DELGADO ${ }^{56}$.

54 Alfonso GONZÁLEZ CARMONA, La materia contencioso-administrativa: teoría, legislación vigente, jurisprudencia, Imprenta de Enrique Rubińos, Madrid, 1891, pp. 45-55: "para justificar la supuesta especialidad de los derechos administrativos fue preciso antes distinguir con diversidad de palabras los dos conceptos idénticos, la Administración administrando y la Administración gestionando"; sin embargo "ni gramatical ni teóricamente hay diferencia entre la Administración, administrando como autoridad y la Administración gestionando como persona jurídica"; "en todos los casos en que la Administración deniega derechos de los particulares ó les impone obligaciones excesivas, ya tales derechos y obligaciones nazcan de la ley, ya nazcan de actos de la libre voluntad, obra siempre como persona jurídica y siempre debe quedar sometida como los demás litigantes de igual condición, á la resolución que sobre tal colisión de derechos diesen en el juicio competente los Tribunales del fuero común"; "no hay entre unos y otros derechos más que la diferencia puramente convencional y arbitraria que, á beneficio de la mayor extensión en las facultades de la Administración, y con menoscabo siempre de las funciones propias de la Justicia, se ha querido establecer".

55 CABALLERO Y MONTES (1902: 198-208) presentó la distinción entre derechos civiles y administrativos como una cuestión doctrinalmente muy debatida de enorme interés tanto para la práctica como para la ciencia. Tras remitirse a las abundantes aportaciones de la Revista de los Tribunales (1891 y 1892), sintetizó las dos posturas fundamentales, de las que eran exponentes destacados, respectivamente, ALFARO Y LAFUENTE, defensor de la justicia administrativa judicializada y del derecho subjetivo de carácter administrativo; y GONZÁLEZ CARMONA, contrario tanto al contenciosoadministrativo como al derecho de carácter administrativo como posición subjetiva diferente del derecho de carácter civil. CABALLERO aceptaba la categoría como elemento del Derecho constituido. Situándose en línea con la jurisprudencia administrativa, consideraba que un derecho "reviste carácter administrativo si la ley que lo regula es ley administrativa"; "el derecho vulnerado ha de estar establecido en algún precepto de carácter administrativo".

56 El profesor GUASP (1940: 11-23) se mostraba proclive a asimilar la jurisdicción contenciosoadministrativa a la civil. Prefería hablar de "acción contencioso-administrativa" en lugar de "recurso contencioso-administrativo" porque aceptar que nos hallamos en este caso ante un verdadero recurso "equivaldría a admitir el carácter procesal de las actuaciones practicadas en la vía gubernativa"; "parece mucho más lógico afirmar que la actividad jurisdiccional no comienza hasta que propiamente intervienen los Tribunales". A su vez, alineándose con GONZÁLEZ CARMONA, rechazaba de lege ferenda la distinción entre el Estado persona jurídica y Estado poder, así como la diferenciación resultante entre derechos civiles y administrativos: "lleva a escindir la unidad del concepto de Estado" y "hace suponer que hay ocasiones en el que el Estado no actúa como tal persona jurídica"; "sin hacer profesión de fe dentro de la escuela vienesa (es decir, sin creer como Kelsen que el Estado no es más que un conjunto de normas jurídicas o la expresión para designar la unidad de tal sistema) parece indudable que [...] el Estado no puede concebirse sino como un sujeto de este mismo orden, es decir, como persona jurídica"; "no aceptamos, pues, la dirección dominante y creemos más defendible la crítica de González". Ahora bien, bajo una perspectiva de lege lata, a la vista de las previsiones de la Ley de la jurisdicción contencioso-administrativa de 1888, consideraba obligado aceptar aquellas distinciones, si bien proponía enunciarlas con términos más correctos, sustancialmente coincidentes con los utilizados un siglo antes por PELÁEZ DEL POZO: "cuando la Administración aparece en una relación jurídica al mismo nivel que los particulares, en coordinación con ellos la relación pertenece al derecho privado; cuando, 


\subsection{Crisis del liberalismo y negación del derecho subjetivo como categoría}

A principios del siglo xx, la crisis de la democracia liberal propició la reafirmación en toda Europa de la incompatibilidad entre la potestad administrativa y el derecho individual y, más precisamente, la idea de que, si la administración infringe límites orientados al interés general, el ciudadano carece de derechos subjetivos correlativos y, por tanto, de la posibilidad de recabar protección judicial; puede todo lo más activar un proceso de carácter revisor destinado principalmente a tutelar el Derecho objetivo.

a) Léon DUGUIT teorizó un concepto "solidarista" de libertad, fundando abiertamente el recurso por excès de pouvoir en la negación del derecho subjetivo como categoría ${ }^{57}$. Maurice HAURIOU contribuyó igualmente a afianzar el contencioso objetivo de anulación, basándolo en la idea de que el Estado aglutina y aliena la conciencia y la voluntad de cada uno de los miembros de la comunidad. Ello justificaría que la administración en "estado de mando" acepte un "compromiso arbitral menor" que la que adopta comportamientos de mera gestión ${ }^{58}$. Dos maestros del Derecho administrativo italiano (Enrico GUICCIARDI ${ }^{59}$ y Santi ROMANO ${ }^{60}$ ) razonaban en igual sentido que el régimen de las potestades administrativas y, en general, la norma que persigue la realización del interés general impone deberes administrativos sin derechos individuales correlativos. A través del recurso de legitimidad y la anulación del acto ilegal el ordenamiento protege principalmente el interés general y solo derivadamente el interés individual (interés legítimo); de ahí las limitadas facultades del juez administrativo y las dificultades en materia de prueba. Ottmar BÜHLER desarrolló para el Derecho administrativo alemán el concepto (restringido) de derecho público subjetivo a través de la llamada teoría de la norma protectora: Schutznormtheorie ${ }^{61}$. Suponía, en sustancia, la negación del derecho individual y de la consecuente protección judicial subjetiva siempre que la norma incumplida respondiera al interés general. El ciudadano perjudicado por su incumplimiento atesoraba un simple interés que no merecía en cuanto tal protección jurídica alguna.

por el contrario, la Administración se mueve en un plano superior, nos hallamos ante una relación de carácter público".

57 Léon DUGUIT, Le droit social, le droit individuel et la transformation de L'État. Conferénces faites a L'École des Hautes Ėtudes Sociales, 3. ${ }^{\mathrm{a}}$ ed., Librairie Félix Alcan, Paris, 1922, pp. 6-40; id., Les transformations du droit public, Librairie Armand Colin, Paris, 1921, p. 185.

58 Maurice HAURIOU, "La gestión administrativa", en Obra escogida, trad. J. A. SANTAMARÍA PASTOR/S. MUÑOZ MACHADO, Instituto de Estudios Administrativos, Madrid, 1976 (original de 1899), pp. 165-181; id., Precis de droit administratif, 8a ed., Sirey, Paris, 1914, p. 436; id., Principes de Droit public, 2. ${ }^{\mathrm{a}}$ ed., Sirey, Paris, 1916, pp. 267-279.

59 Enrico GUICCIARDI, "Concetti tradizionali e principii riconstruttivi nella giustizia amministrativa”, en Studi di giustizia amministrativa, Edit. Torinese, Torino, 1967 (original de 1937), pp. 1-23.

60 Santi ROMANO, Fragmentos de un diccionario jurídico, Ediciones jurídicas Europa-América, Buenos Aires, 1964 (original de 1947), pp. 89-95.

${ }^{61}$ Ottmar BÜHLER, Die subjecktiven öffentlichen Rechte und ihr Schutz in der deutschen Verwaltungsrechtsprechung, W. Kohlhammer, Berlin, 1914. 
b) Entre nosotros, el profesor José GASCÓN Y MARÍN acertó a captar esta tendencia del Derecho administrativo europeo, destacando que, en realidad, arraigaba en los orígenes mismos del contencioso-administrativo ${ }^{62}$. Este profesor, al igual que la generalidad de los autores espańoles ${ }^{63}$, rechazaba en perfecta consonancia con los europeos que los límites impuestos a la administración en beneficio del interés general pudieran funcionar como derechos subjetivos correlativos merecedores, en cuanto tales, de protección judicial plena. Reconocían solo una posición subjetiva menor que empezaba a retratarse también entre nosotros con el significante "interés legítimo", tanto en los escritos académicos como en la legislación de régimen local ${ }^{64}$. Ciertamente, a través del concepto de "interés", los autores y la legislación pretendían aumentar el control contencioso-administrativo; en particular, impedir que la presencia de elementos discrecionales funcionara como óbice de admisibilidad. Ahora bien, no debe perderse de vista la impronta autoritaria de la noción; respondía a la ideología que afirmaba siempre la superioridad del interés general sobre el particular, negaba que las leyes administrativas atribuyeran derechos individuales, configuraba el proceso como un mecanismo anulatorio para la protección del Derecho objetivo y rechazaba en consecuencia que el particular pudiera obtener tutela judicial plena frente al incumplimiento de las normas que limitan el ejercicio de las potestades administrativas ${ }^{65}$.

El nazismo llevó al paroxismo el concepto autoritario de derecho imperfecto o interés. Al interpretar que todo el orden jurídico debía entenderse establecido al exclusivo servicio de la comunidad, la teoría de los derechos públicos subjetivos arrojaba una

62 José GASCÓN Y MARÍN, Las garantías jurídicas del ciudadano y la evolución del recurso contencioso-administrativo, Madrid, 1917, pp. 20, 24, 37: "[T] oda la tendencia moderna va en pro, no de la mera consideración del poder ejercido por un individuo ó ejercido por una autoridad, sino de la finalidad objetiva del ejercicio de ese mismo poder, de la realización del bienestar general, del bien público [...]. Desde el momento en que aparezca que aquello que el juzgador tiene que atender no es meramente la consideración jurídico-subjetiva del que manda ó la situación subjetiva del que debía obedecer como administrado, sino examinar si ha sido ó no cumplido el fin para el cual fue creado, instituido el servicio público, el problema es completamente distinto [...]. La ampliación que la nueva materia administrativa lleva consigo se traduce forzosamente en la base de carácter objetivo que se dé á todo el elemento jurisdiccional". Subrayó igualmente la importancia que nuestros primeros administrativistas asignaban al contencioso-administrativo como instrumento de protección del "interés social".

63 GASCÓN Y MARÍN (1917: 26, 38, 50); Recaredo FERNÁNDEZ DE VELASCO, La "acción popular" en el Derecho administrativo, Reus, Madrid, 1920, pp. 15-35, 52-55); id., El acto administrativo (exposición doctrinal y estudio del Derecho español), prólogo de M. HAURIOU, Victoriano Suárez, Madrid, 1929, pp. 273-287; José María PI Y SUNEER, Lo contencioso-administrativo, versión taquigráfica revisada, completada y anotada del curso profesado en la Facultad de Derecho de la Universidad de Barcelona, Centro de Administración Municipal, Barcelona, 1928, p. 32; Carlos GARCÍA OVIEDO, "El recurso contencioso-administrativo en la nueva Constitución española, Revista de Derecho Público, 1932, pp. 298-299.

64 Estatuto municipal de 1924 (art. 253), Ley municipal de 1935 (art. 223), Ley de bases de régimen local de 17 de julio de 1945 [base 59, párrafo segundo, letra b)] y texto articulado de 1950 [art. 386.3 b)]. Cfr. Sabino ÁLVAREZ-GENDÍN Y BLANCO, "Acción popular y recursos administrativos contra los actos de la Administración local”, $R A P$, núm. 11, 1953, pp. 221-267.

${ }^{65}$ Más detalles en MEDINA ALCOZ (2016: 170-181). 
conclusión clara: el Derecho objetivo nunca atribuye verdaderos derechos individuales. El derecho público subjetivo desaparecía pura y simplemente sin derogación de la Constitución de Weimar de 1919, sin reformas legislativas y sin necesidad de variar un ápice la dogmática decimonónica que lo alumbró. Antes bien, la extinción de los derechos era en cierto modo una consecuencia de ella ${ }^{66}$. El Estado de esclavos dejó de ser solo la solución lógicamente posible imaginada (y rechazada solo en términos morales) por JELLINEK para convertirse sin más en regulación vigente. La literatura jurídica lo afirmaba abiertamente: "en lugar del principio individualista se halla ahora el de la comunidad como fundamento de Derecho público, incompatible con la idea de personalidad jurídica" ${ }^{67}$. Aún más claramente: "el concepto de libertades individuales de la persona en oposición a la autoridad del Estado" tiene "que desaparecer; no es conciliable con el principio nacionalista del Reich" porque "no hay libertades individuales de la persona que caigan fuera del dominio del Estado ni que deban ser respetadas por el Estado" ${ }^{68}$. De modo que la posición del ciudadano frente al ordenamiento (y ante las obligaciones que este impone a la administración) era siempre de mero interés; tenía solo las ventajas que indirectamente recibía de él, esto es, un efecto reflejo del Derecho objetivo.

El problema no era tanto que el iuspositivismo imperante en la cultura jurídica permitiese al Estado reformar el orden jurídico para suprimir derechos; era, más bien, que una concreta teoría desarrollada dentro de él -la que afirmaba la intrínseca incompatibilidad entre el interés general y el derecho subjetivo- pudo ser utilizada por el nacionalsocialismo para negar toda posición individual de poder frente al Estado sin necesidad de cambiar el ordenamiento jurídico ${ }^{69}$. De modo que, al negar el derecho subjetivo y afirmar el contencioso objetivo, el Derecho público nacionalsocialista se apoyó en una idea que el Derecho administrativo de toda Europa, no solo Alemania, venía formalizando teóricamente y desarrollando al menos desde mediados del siglo xIx: la supremacía del Estado sobre el individuo, del interés general sobre el particular, la incompatibilidad intrínseca entre el derecho individual y el interés general.

En el año 1942, el profesor Antonio ROYO VILLANOVA se hizo eco de que el derecho subjetivo había desaparecido dentro del Derecho administrativo alemán: "el nacionalsocialismo solo reconoce al individuo como miembro de la comunidad,

66 Durante sus primeros años, el nazismo alumbró un "alud” de leyes y decretos, pero en ningún momento sintió la necesidad de abolir oficialmente la Constitución de Weimar. Cfr. Hannah ARENDT, Los orígenes del totalitarismo, Taurus, Madrid, 1998 (original de 1951), pp. 479-483.

67 Las palabras son de Reinhard HÖHN, Die Wandlung im staatsrechtlichen Denken, Hanseatische Verlagsanstalt, Hamburg, 1934. Tomo la cita de Francisco SOSA WAGNER, Maestros alemanes del Derecho público (II), Marcial Pons, Madrid, 2004, p. 351.

68 Ernest Rudolf HUBER, Verfassungsrecht des grossdeutschen Reiches, 2. a ed., Hanseatische Verlagsanstalt, Hamburg, 1939. Tomo la cita de Leonard PEIKOFF, The ominous parallels, Meridian, New York, 1982, p. 7.

69 De hecho, los juristas alemanes se apoyaban explícitamente en autores como GIERKE y DUGUIT. Lo destaca John Maurice KELLY, Storia del pensiero giurico occidentale, Il Mulino, Bologna, 1997, pp. 439-440. 
como miembro de su familia, de su sindicato, de su nación. Desaparece, pues, en el nacionalsocialismo el derecho público subjetivo, al extinguirse su contenido, esto es, el reconocimiento de la libertad individual, de los intereses individuales" ${ }^{70}$. A la vista del "auge y desarrollo del interés nacional" dentro del Derecho administrativo español y de la correlativa pérdida de importancia de los "intereses particulares", el autor se pregunta: "¿qué amplitud tiene en el nuevo régimen la noción de derecho público subjetivo?, ¿puede afirmarse, como sostiene la moderna doctrina alemana, que ha desaparecido tal noción?”. En consonancia con toda la doctrina administrativista europea, entiende que también en el Derecho espańol la norma destinada al interés general no atribuye derechos por definición; el individuo que padece su incumplimiento carecerá de protección jurídica o, todo lo más, obtendrá una "protección indirecta", esto es, la que pueda resultar para el particular de los recursos que el legislador haya querido conceder para "el logro de los intereses generales y el cumplimiento de la ley": "De aquí que haya que distinguir los derechos subjetivos y los intereses legítimos"; solo los primeros merecen una tutela judicial propiamente dicha. Siendo este el planteamiento, no quedaba más remedio que admitir que la noción de derecho subjetivo también entre nosotros "se ha reducido considerablemente", no solo por "el gran desarrollo de la potestad discrecional", sino sobre todo por "la exaltación del interés nacional como fin supremo de la Administración pública": el Derecho administrativo del "Nuevo Estado" no es "un conjunto de reglas encaminadas a garantir los derechos de los particulares frente al poder de la Administración, sino que, como todo el Derecho público de un país, tiende a regular la vida nacional, de manera que pueda realizarse la misión histórica de la nación".

En efecto, el individuo del "Nuevo Estado" solo contaba con derechos subjetivos (y, en consecuencia, con la posibilidad de obtener protección plena) en las relaciones paritarias regidas por el Derecho civil y ventiladas en la jurisdicción ordinaria. Frente a las potestades de la administración central carecía incluso del tradicional derecho secundario de carácter administrativo; no podía obtener siquiera la protección menor que dispensaba la jurisdicción contencioso-administrativa habida cuenta de que la Ley de 27 de agosto de 1938 la había suprimido, manteniéndola solo respecto de las resoluciones locales ${ }^{71}$. La Ley de 18 de marzo de 1944 restableció el recurso contencioso-

${ }^{70}$ Antonio ROYO VILLANOVA, Elementos de Derecho administrativo, t. I., 17. a ed. corregida y aumentada con la colaboración de su hijo Segismundo, Librería Santarén, Valladolid, 1942, pp. 70-71; t. II, 799-802. Hizo la misma apreciación el profesor José GASCÓN Y MARÍN, Derecho administrat ivo. Principios y legislación española, t. I, Doctrina general, 7.a ed., C. Bermejo, Madrid, 1941, p. 162): "El acentuarse el carácter objetivo del 'estado de derecho' en los nuevos regímenes políticos ha planteado el problema de la existencia o no de derechos públicos subjetivos, por diferenciar la protección del derecho de la comunidad de la del derecho verdaderamente individualizado [...]. El Derecho público subjetivo de la doctrina individualista liberal no se armoniza con los principios del régimen alemán". En la misma línea, Sabino ÁLVAREZ-GENDÍN, Manual de Derecho administrativo, Librería General, Zaragoza, 1941, pp. 229-231.

71 Ahora bien, el profesor ROYO VILLANOVA (1942: t. I, 70-71; t. II, 799-802), a diferencia de los autores nacionalsocialistas, consideraba esencial asegurar una justicia administrativa profesionalizada completamente independiente, haciendo lo posible por desactivar la Ley de 27 de agosto de 1938: 
administrativo, pero no del todo; quedaron excluidas algunas materias (depuraciones, responsabilidades políticas, desbloqueo, prensa, propaganda y determinadas cuestiones de personal). Se creó, a su vez, un recurso administrativo especial (llamado de "agravios", sucesivo al ordinario de reposición) para una de aquellas materias (cuestiones de personal) por "vicio de forma o infracción expresa de una Ley, un reglamento o precepto administrativo"; lo resolvía el Consejo de Ministros previo informe del Consejo de Estado (art. 4). Se regresaba así a una justicia administrativa retenida destinada a la protección de la legalidad objetiva ${ }^{72} \mathrm{o}$, todo lo más, de una posición activa menor penetrada por el interés general (interés legítimo) ${ }^{73}$. Lo afirmaba la propia exposición de motivos de la Ley al declarar que esta nueva jurisdicción "de orden administrativo" sirve para corregir "errores de la Administración", no para reparar "verdaderas conculcaciones de derechos". La "jurisprudencia de agravios" desarrolló al efecto el concepto autoritario de "interés": "la finalidad principal del recurso de agravios no es la de proteger un derecho, sino la de restaurar la legalidad violada" (dictamen del Consejo de Estado de 24 de noviembre de 1948); "a tenor de lo dispuesto en el artículo 4. ${ }^{\circ}$ de la Ley de 18 de marzo de 1944, el recurso de agravios puede fundarse tanto en infracción legal como en vicio de forma, lo cual indica que la legitimación no viene determinada por la titularidad de un derecho subjetivo lesionado, ya que no puede invocarse nunca un derecho subjetivo a la forma", debe ostentarse "un interés personal, directo y legítimo en que se revoque la resolución impugnada" (Orden de 12 de noviembre de 1949).

De acuerdo con GASCÓN Y MARÍN, el restablecimiento de la jurisdicción contencioso-administrativa y la creación de la nueva justicia administrativa de agravios pretendían intensificar el "estado de Derecho objetivo, como es característica de los nuevos regímenes políticos, en el que se proteja la situación reconocida a los particulares en interés de la comunidad política"; suponen "la afirmación del principio de legalidad como norma de actuación de los servicios públicos, como principio básico de la actividad decisoria de las actividades administrativas y como interés supremo del Estado, de que las leyes y disposiciones legales generales dictadas por los órganos competentes tengan siempre su conveniente efectividad al ser aplicados en casos concretos" ${ }^{34}$.

\footnotetext{
"Si las Diputaciones y Ayuntamientos, entidades dotadas de Poder público, han de observar las leyes, siendo los tribunales los encargados de velar por su cumplimiento, ¿por qué la Administración central ha de mirar con recelo a los Tribunales administrativos?". El concepto "autoritario" de interés constituyó la palanca que de algún modo permitía disimular la defensa de esta maltrecha institución liberal: la afirmación del Estado autoritario "no significa que desaparezcan todos los intereses individuales para el Derecho"; algunos de estos "merecen y obtienen la protección del Derecho" a través de la "posibilidad de acudir a una autoridad, especialmente de carácter judicial"; "verdad es que estos intereses particulares solo obtienen protección en tanto que no estén en pugna con el supremo interés nacional, pero no es menos cierto que una vez garantizado el bien de la nación, nada se opone a que los intereses legítimos de los ciudadanos alcancen una tutela eficaz".

72 Cfr. Antonio PÉREZ HERNÁNDEZ, Naturaleza juridica del recurso de agravios, Publicaciones del Consejo de Estado, Madrid, 1954.

73 Fernando GARRIDO FALLA, "El interés para recurrir en agravios", RAP, núm. 9, 1952, pp. 157-174.

${ }^{74}$ José GASCÓN Y MARÍN, "Restablecimiento del recurso contencioso-administrativo", Revista de Estudios de la Vida Local, núm. 14, 1944, pp. 271-274.
} 


\section{DEL ESTADO AUTORITARIO AL ESTADO CONSTITUCIONAL}

\subsection{La protección de los derechos: el derecho subjetivo como autonomía de la voluntad}

\subsubsection{La recuperación del concepto iusnaturalista de derecho subjetivo, en general}

Tras la Segunda Guerra Mundial, cambia el espíritu del tiempo. La Europa occidental rechaza firmemente los horrores de la guerra, el totalitarismo y la estadolatría de la cultura político-jurídica del siglo XIx. En su lugar recupera abiertamente los postulados básicos del iusnaturalismo en la forma y en el fondo. En cuanto a la forma, la declaración de derechos, texto emblemático de las Revoluciones liberales, reaparece a través de tratados internacionales y nuevas constituciones. Respecto del fondo, estas nuevas declaraciones reafirman sin ambages aquellos postulados liberales. Proclaman frente al Estado derechos, afirmándolos universales, inviolables e inherentes al hombre en cuanto tal y expresando su propósito de entroncar directamente con la Escuela de Derecho natural ${ }^{75}$. En consonancia con la lógica universalista y antinacionalista inherente a estas declaraciones, los Estados europeos aceptaron someterse a la jurisdicción del Tribunal Europeo de Derechos Humanos y emprendieron un proceso de integración en entidades supranacionales, antecedentes de la actual Unión Europea.

La reafirmación de los postulados liberales y la integración europea supusieron un giro copernicano que obligó en toda Europa a abrir un proceso de refundación del Derecho administrativo. Se trataba, dicho esquemáticamente, de trasformar regímenes totalitarios (u ordenamientos ajustados a los postulados del Estado de Derecho objetivo) en un Estado de derechos (subjetivos) ${ }^{76}$. La idea de derecho subjetivo como ámbito de libertad enraizado en la capacidad del individuo para elegir sus fines cristalizó en las normas del Derecho administrativo. Los principios de corre-

75 "Nosotros los pueblos de las Naciones Unidas [estamos] resueltos a preservar a las generaciones venideras del flagelo de la guerra que dos veces durante nuestra vida ha infligido a la Humanidad sufrimientos indecibles [y] a reafirmar la fe en los derechos fundamentales del hombre, en la dignidad y el valor de la persona humana, en la igualdad de derechos de hombres y mujeres" (Carta de las Naciones Unidades de 1945); "[ $t$ ] odos los seres humanos nacen libres e iguales en dignidad y derechos y, dotados como están de razón y conciencia, deben comportarse fraternalmente los unos con los otros" (art. 1 de la Declaración Universal de Derechos Humanos de 1948 de las Naciones Unidas); los miembros del Consejo de Europa, "[r]eafirmando su profunda adhesión a estas libertades fundamentales", han resuelto "asegurar la garantía colectiva de algunos de los derechos enunciadas en la Declaración Universal" (exposición de motivos del Convenio europeo para la protección de los derechos humanos y las libertades fundamentales de 4 de noviembre de 1950); [1] a República reconoce y garantiza los derechos inviolables del hombre (art. 2 de la Constitución italiana); "[l]a dignidad humana es intangible, [r] espetarla y protegerla es obligación de todo poder público", [e]l pueblo alemán, por ello, reconoce los derechos humanos inviolables e inalienables como fundamento de toda comunidad humana, de la paz y de la justicia en el mundo" (art. 1 de la Ley Fundamental de Bonn).

76 Sobre el Estado de derechos, Gustavo ZAGREBELSKY, Il diritto mite, Einaudi, Torino, 1992, p. 84 . 
latividad y protección plena elaborados por la Escuela iusnaturalista y proyectados únicamente hasta entonces sobre el Derecho privado y las relaciones horizontales entre el ciudadano y la administración, se recuperaron para las relaciones verticales de mando o poder. Los límites normativos que obligan a la administración empezaron así a operar como derechos subjetivos correlativos; derechos que, en cuanto tales, merecen tutela judicial efectiva. El fin colectivo perseguido por la norma que impone obligaciones al poder dejó de funcionar como pretexto para rebajar la posición jurídica del ciudadano a derecho "secundario" o mero "interés", excluyendo el acceso a la jurisdicción o la protección judicial plena. A efectos de afirmar o negar la tutela judicial efectiva, lo relevante pasó a ser no ya la finalidad de la norma, sino los efectos de su inobservancia; no que esa norma tutele intereses individuales, sino que su incumplimiento perjudique intereses individuales. De modo que, en el marco del nuevo Estado de derechos, la tendencia ha sido a que todo el Derecho administrativo objetivo sea derecho subjetivo bajo la condición de que el incumplimiento del primero afecte singularmente a quien esgrime el segundo en el proceso. En resumen: el Derecho administrativo rescató el viejo concepto de derecho subjetivo como autonomía de la voluntad.

El nuevo constitucionalismo europeo subjetivó así el Derecho administrativo lo que, en punto a las potestades, se concretó en que si el poder es reglado (o si la administración ya consumió la discrecionalidad que liberaba la norma) el ciudadano es acreedor de un derecho subjetivo a una resolución de contenido específico. Si la potestad es discrecional (y si la administración no agotó completamente los márgenes de configuración otorgados por la norma) el ciudadano es acreedor del derecho a una resolución administrativa sin contenido predeterminado, pero libre de vicios. A la obligación administrativa de ejercer correctamente la discrecionalidad (o, si estuviera reducida a cero, de adoptar la única solución legalmente posible) le sigue un correlativo derecho subjetivo a obtener una decisión conforme a Derecho (o a obtener una decisión en un determinado sentido). La subjetivación del Derecho administrativo sustantivo ha ido de la mano de la subjetivación del proceso administrativo. Una no se entiende sin la otra: quien sufre las extralimitaciones del poder, en cuanto titular de derechos, tiene constitucionalmente garantizada una protección plena, lo que implica garantías de imparcialidad e igualdad de armas, así como la posibilidad de practicar prueba y obtener condenas a hacer ${ }^{77}$.

La subjetivación del Derecho administrativo se ha realizado en Europa a través de múltiples reformas procesales y del activismo doctrinal y judicial. Unas y otro lograron introducir las garantías de imparcialidad y restablecimiento pleno consubs-

77 En este sentido, refiriéndose al Derecho alemán: Hartmut MAURER, Derecho administrativo. Parte General, Marcial Pons, Madrid, 2011, p. 201. En la misma línea, para el ordenamiento italiano: Leonardo FERRARA, Dal giudizio di ottemperanza al processo di esecuzione: la dissoluzione del concetto di interesse legittimo, Giuffrè, Milano, 2003, pp. 150-166. Respecto de España y otros sistemas jurídicos europeos: MEDINA ALCOZ (2016: 217-229). 
tanciales al derecho subjetivo ${ }^{78}$. La "ficción" ha sido decisiva en esta evolución: los juristas se han apoyado en ella para hacer realidad la cultura de los derechos dentro del marco legal y conceptual autoritario heredado del pasado. Ello ha dado lugar a que sistemas jurídicos que proporcionan ya grados equiparables (y nada desdeñables) de protección individual frente a las extralimitaciones administrativas no siempre utilicen formalmente la lengua de los derechos y que dispongan todavía hoy de teorías aparentemente muy diversas sobre las situaciones activas del administrado. Cada ordenamiento ha ingeniado fórmulas locales para salvar las mismas dificultades, esto es, las planteadas por los conceptos del viejo Derecho administrativo.

En Francia, durante muchos años el Consejo de Estado y la doctrina académica mantuvieron el carácter objetivo del recurso por exceso de poder ${ }^{79}$, pero evitando ya resaltar la teoría material de las situaciones activas que aquel carácter presupone. Dejaron de decir que el recurso por exceso de poder se funda en la inexistencia del derecho subjetivo como categoría (DUGUIT) o en el Estado como institución que aglutina y aliena la conciencia y la voluntad de cada uno de los miembros de la comunidad (HAURIOU). Se evolucionó finalmente hacia la subjetivación del Derecho administrativo, tal como reconocen abiertamente ya los administrativistas franceses ${ }^{80}$. La conversión del administrado en titular de derechos y, en cuanto tal, en sujeto merecedor de tutela judicial efectiva frente a la administración también en el recurso por exceso de poder es una de las transformaciones recientes más relevantes del Derecho administrativo francés. Si antes gravitaba alrededor del interés general como interés superior al particular, pasó a pivotar en gran medida en torno al individuo; la afirmación de los derechos fundamentales y la jurisprudencia del Tribunal Europeo de Derechos Humanos favorecieron la idea del "derecho" frente a la del simple "interés" ${ }^{81}$. En estrecha conexión con esta renovada teoría de las

${ }^{78}$ El profesor GARCÍA DE ENTERRÍA (2007: 125-148), tras describir las reformas procesales acometidas en los diferentes ordenamientos europeos, constató que habían colocado el contenciosoadministrativo en el plano del proceso civil, como lugar de confrontación de pretensiones equivalentes en cuanto expresivas de la titularidad potencial de derechos. No se habrían limitado a corregir levemente el formato de la justicia administrativa, preservando su clásica vocación de exclusivo servicio a los intereses generales y el Derecho objetivo; habrían alterado su mismo fundamento, que es el derecho fundamental a la tutela judicial efectiva de cualquier "derecho material" del que sea titular el ciudadano. La idea se desarrolla también en GARCÍA DE ENTERRÍA, Problemas del Derecho público al comienzo de siglo, Civitas, Madrid, 2001.

79 Avanzado el siglo xx eran aún pocos los autores críticos con la configuración objetiva del recurso por exceso de poder: Bruno KORNPROBST, La notion de partie et le recours pour excès de pouvoir, Librairie générale de droit et de jurisprudence, Paris, 1959; Jean RIVERO, "Le huron au Palais Royal ou réflexions sur le récours pour excés de pouvoir”, Dalloz, Chroniche, VI, 1962, pp. 37-40. Se ha referido a ello: GARCÍA DE ENTERRÍA (2007: 79-118).

${ }^{80}$ Cfr. Norbert FOULQUIER, Les droits subjectifs des administrés. Emergence d'un concept en droit administratiffrançais du XIXè au XXè siècle, Dalloz, Nouvelle Bibliothèque de thèses, t. 25, Paris, 2003; $i d$., "L'analyse du discours juridique: le concept de droit subjectif en droit administratif", en Sur la portée sociale du droit. Usages et légitimité du registre juridique, PUF, 2005.

81 Patrick FRAISSEIX, "La subjectivisation du droit administratif", Les petites affiches, núm. 207, 2004, p. 12 ; id., "La révolution méthodologique du juge de l'excès de pouvoir", Les petites affiches, núm. 180, 2005. 
situaciones jurídico-subjetivas, aparecieron nuevas instancias judiciales (Tribunales administrativos en 1953, Cortes administrativas de apelación en 1987) y jurisdicciones especializadas a la vez que se admitió que el recurso por exceso de poder activa un verdadero proceso entre partes que no puede desentenderse de las pretensiones particulares. Las reformas legislativas de los años ochenta y noventa del pasado siglo han ampliado los poderes del juez administrativo; aquel proceso produce ya no solo anulaciones de actos administrativos, sino también condenas a hacer. El Código de Justicia administrativa de 4 de mayo de 2000 establece ahora un régimen de medidas cautelares (référés) y ejecución de Sentencias que expresa a las claras hasta qué punto el contencioso-administrativo sirve a la tutela directa de derechos individuales. Hay también medidas que, cumpliendo exigencias del Tribunal Europeo de Derechos Humanos, desarrollan garantías (oralidad, plena contradicción, entre otras) y evitan que los miembros del Consejo de Estado decidan un asunto en ejercicio de funciones jurisdiccionales si han intervenido antes en él en cumplimiento de funciones consultivas (Decretos de 6 de marzo de 2008 y 7 de febrero de 2009). Se está ante reformas que abundan en una subjetivación del contencioso-administrativo que presupone la subjetivación del Derecho administrativo sustantivo ${ }^{82}$.

En Italia, la Constitución de 1948 no alteró la tradicional configuración de la justicia administrativa. Más aún, su Título III (relativo al Gobierno) seguía mezclando en un órgano vinculado al poder ejecutivo (Consejo de Estado) funciones de consulta jurídico-administrativa y de control; control a la administración que, según la literalidad del art. 100 de la Constitución, debía realizarse dentro de la administración para la protección de meros "intereses legítimos". La estrategia académica y judicial consistió entonces en enmascarar el significado legal del interés legítimo (el resultante de un Derecho positivo que tutela solo parcialmente al ciudadano enfrentado al poder) y, simultáneamente, pergeñar soluciones que aseguran mayor protección judicial individual (la que no reconoce la ley). Por ejemplo, un brillante y muy influyente profesor, Mario NIGRO, aceptaba que la justicia administrativa decimonónica estaba esencialmente plasmada en la Constitución, pero a través de su razonamiento jurídico conseguía que los resultados fueran radicalmente nuevos; asignaba al "interés legítimo" un contenido que ocultaba su inequívoca impronta autoritaria (lo definía como poder de influir sobre la administración en orden a alcanzar el bien de la vida auspiciado a través del procedimiento) al tiempo que superaba el dogma legal del contencioso exclusivamente anulatorio a través de una elaboración audaz (la teoría del doble efecto "ripristinatorio" y "conformativo" de la Sentencia anulatoria) ${ }^{83}$.

82 Distingue esa doble dimensión, procesal y sustancial, del fenómeno de la "subjetivación": Silvie SCHMITT, "L'evolution de la subjectivisation du contentieux administratif en France et en Italie", Liber amicorum Jean-Claude Escarras: la communicabilité entre les systèmes juridiques, Bruylant, Bruxelles, 2005, pp. 956-967.

83 Se trata de un elaborado planteamiento destinado a que el juez administrativo, en el marco de un proceso legalmente configurado como impugnatorio y referido exclusivamente al acto administrativo producido en el pasado, pueda de algún modo condicionar la fase administrativa sucesiva, de un modo similar a una Sentencia estrictamente condenatoria: Mario NIGRO, Giustizia amministrativa, 6. ${ }^{\text {a }}$ ed. revisada por E. CARDI y A. NIGRO, Il Mulino, Bologna, 2002, pp. 311-323. Un expediente 
La protección del ciudadano se ha desarrollado así mediante expedientes locales destinados a justificar la garantía judicial de los derechos, pero veladamente, como si ello fuese compatible con los presupuestos autoritarios de aquella antigua legislación procesal. Esta es, según creo, la clave de lectura de la gran variedad de definiciones circulantes del concepto de "interés legítimo" y la razón de que el debate cisalpino en torno a la figura resulte un enigma indescifrable para el administrativista extranjero.

A principios del siglo $\mathrm{xx}$, tras una serie relevante de reformas procesales, el recurso a la ficción dejó de ser necesario ${ }^{84}$ : el juez administrativo italiano tiene ya plenos poderes de cognición de los hechos, está autorizado a dictar pronunciamientos condenatorios contra la administración (se discute si la condena cabe en supuestos típicos o es ya válida con carácter general) ${ }^{85}$, puede ir más allá del control de legalidad y ejercer por sí la discrecionalidad administrativa en determinadas materias (giurisdizione estesa al merito en asuntos electorales, sanciones económicas, demarcaciones territoriales y algunas denegaciones de autorización) y hace tiempo que dispone ( $\mathrm{y}$ utiliza) potentes instrumentos para forzar al cumplimiento de sus Sentencias; cabe el ejercicio sustitutivo (a través de la figura pseudoadministrativa del comissario) de la discrecionalidad ${ }^{86}$. Ahora bien, el "interés legítimo" no se convirtió por ello en un significante vacío de todo significado jurídico. La Constitución (art. 103) y el Código del Proceso Administrativo de 2010 (art. 7) aún asignan a la jurisdicción administrativa la protección de los "intereses legítimos" "concernidos en el ejercicio (o falta de ejercicio) de la potestad". Se entiende entonces que se diga que el interés legítimo continúa siendo la posición activa frente a la potestad a los efectos del reparto competencial, aunque deba calificarse de "derecho subjetivo" desde la perspectiva de las garantías ${ }^{87}$. De este modo, cobra fuerza un concepto normativo

altamente artificioso y funcionalmente idéntico apareció después de que el juez administrativo quedará al fin facultado para ordenar la indemnización de daños en concepto de responsabilidad civil de la administración (Ley 205/2000, de 21 de julio). Se dijo que pasaban a estar habilitadas cualesquiera condenas a hacer a la administración, no solo las relativas a la reparación de daños, por la siguiente razón: el juez administrativo que anula una denegación está autorizado a ordenar el otorgamiento del acto favorable en concepto de responsabilidad civil extracontractual, como si tal condena realizase una forma de resarcimiento in natura o en forma específica: Diego VAIANO, Pretesa di provvedimento e processo amministrativo, Giuffrè, Milano, 2002, pp. 295-370.

${ }^{84}$ Tras la reforma de 1999, la Constitución italiana reconoce abiertamente que las garantías del “juicio justo" deben proyectarse sobre "todos los procesos", también los conducidos en la jurisdicción administrativa (art. 111), tal como dispone expresamente ya el nuevo Código del Proceso Administrativo, aprobado por Decreto legislativo 104/2010, de 2 de julio (art. 2). A su vez, la Sentencia 500/1999, de 22 de julio, del Tribunal de Casación y reformas legislativas recientes (Decreto-legislativo 80/1998, de 31 de marzo; Ley 205/2000, de 21 de julio), singularmente el mencionado Código, han transformado enormemente el contexto que pergeñó el concepto de interés legítimo.

${ }^{85}$ Cfr. TRAVI (2012: 198-202, 207-216).

86 Cfr. Isaac MARTÍN DELGADO, La ejecución subrogatoria de las sentencias contencioso-administrativas, Iustel, Madrid, 2006, pp. 23-27.

${ }^{87}$ La mayor parte de los autores que desarrolla estas ideas está vinculada a la llamada Escuela florentina: Andrea ORSI BATTAGLINI, "Attività vincolata e situazioni soggettive", Rivista trimestrale di diritto processuale, 1988, pp. 3 ss.; id., Alla ricerca dello Stato di diritto. Per una giustizia "non amministrativa", Giuffrè, Milano, 2005; Domenico SORACE, "Promemoria per una nuova voce 'atto 
afín al propuesto por el profesor Eduardo García de Enterría para nuestro sistema jurídico: el interés legítimo como clase de derecho subjetivo.

En Alemania, dentro del renovado marco proporcionado por la Ley Fundamental de Bonn de 23 de mayo de 1949, la imagen del hombre libre se impuso rotundamente: el individuo es "por entero y por principio" sujeto y sujeto de derechos en todo el ordenamiento jurídico ${ }^{88}$. El "derecho subjetivo" se convierte en una figura de Derecho constitucional ${ }^{89}$. Se afirma como instituto constitucionalmente garantizado (art. 19.4 LF) y condición esencial para la existencia misma del Estado de Derecho. En consonancia con estos imperativos constitucionales, la Ley de 21 de enero de 1960 de la jurisdicción administrativa ha regulado un proceso netamente subjetivo destinado a averiguar si la administración ha lesionado un derecho individual (individualschützchende Auffassung). La "lesión de derecho subjetivo" o "lesión jurídica" (Rechtsverletzung) se produce y debe repararse si la administración ha incumplido la norma jurídico-administrativa y si tal incumplimiento ha perjudicado o afectado singularmente al recurrente. Se parte de que la obligación impuesta a la administración funciona en el proceso como derecho subjetivo correlativo siempre que el recurrente haya sufrido un perjuicio como consecuencia de su infracción y ello tanto si quien recurre es el destinatario directo de la medida administrativa como un tercero (p. ej., inquilinos o poseedores que accionan contra licencias para la construcción de instalaciones que producen molestias) ${ }^{90}$. A su vez, con el fin de asegurar la reparación plena del derecho subjetivo lesionado, la Ley formula el derecho a la acción (art. 40) y apodera al juez para dar respuesta a las pretensiones del recurrente; pretensiones no solo de anulación de actos administrativos (Anfechtungsklage, art. 42), sino también de condena al dictado de un acto administrativo (Verpflichtungsklage, art. 42) y a la ejecución de cualesquiera otros comportamientos legalmente exigibles a la administración (allgemeine Leistungsklage, art. 43.2).

Ciertamente, por el peso de la tradición, el sistema alemán conserva la Schutznormtheorie, negando en consecuencia que la norma que impone una obligación a la administración esté atribuyendo derechos subjetivos correlativos, aunque su incumplimiento produzca perjuicios individualizados, si tiene por finalidad objetivos colectivos. No obstante, la mayor parte de los desarrollos, sin cuestionar la teoría, ha pretendido desactivar sus efectos. Se trata de expedientes funcionalmente idénticos a las creativas elaboraciones latinas: introducen garantías solapadamente, sin discutir un marco legal o conceptual que, en realidad, conduciría a asegurar a la adminis-

amministrativo'”, en Scritti in onore di Massimo Severo Giannini, t. III, Giuffrè, Milano, 1988, pp. 47 y ss.; Leonardo FERRARA, Diritti soggettivi ad accertamento amministrativo, Cedam, Padova, 1996; id. (2003: 130-166); Chiara CUDIA, Funzione amministrativa e soggettività della tutela. Dall'eccesso di potere alle regole del rapporto, Giuffrè, Milano, 2008, pp. 327-378.

88 Reiner WAHL, Los últimos cincuenta años de Derecho administrativo alemán, Marcial Pons, Madrid, 2013, p. 39.

89 Reiner ARNOLD, "Legittimazione a ricorrere e situazioni soggettive nell'ordinamento tedesco", en Colloquio sullinteresse legittimo. Atti del Convegno in memoria di Umberto Pototschnig, Milano, 19 aprile 2013, Jovene, Napoli, 2014, p. 66.

90 Cfr. ARNOLD (2014: 63) y GONZÁLEZ-VARAS IBÁÑEZ (1993: 113-119). 
tración amplias esferas de inmunidad. Por eso, el debate sobre la teoría de la norma protectora acaba convirtiéndose en una discusión local, impenetrable para el jurista extranjero, exactamente igual que la controversia italiana sobre el interés legítimo o la tendencia francesa a afirmar el carácter objetivo del recurso por exceso de poder sin explicar a las claras que ello implica la negación pura y simple de los derechos individuales frente a la puissance publique ${ }^{91}$.

\subsubsection{La recuperación del concepto iusnaturalista de derecho subjetivo en el Derecho administrativo español, en particular}

En los años cincuenta se abrió también en España un proceso de refundación del Derecho administrativo "por insólito que pueda parecer, a primera vista, y hasta por antipático que nos resulte el hecho de tener que reconocerlo" ${ }^{2}$. El Derecho administrativo se convirtió en "el puente que enlazaba, un tanto inesperadamente, al franquismo con las democracias occidentales: un sucedáneo democrático, ciertamente, pero cabalmente por ello más valioso y más necesario que el producto auténtico" ${ }^{93}$. Los

91 La doctrina alemana, por un lado, insiste en que la finalidad de interés general de una norma excluye el derecho (y, por tanto, su justiciabilidad) solo si se presenta en soledad, sin la compañía de fines de interés particular; y, por otro, localiza intereses privados en normas que, en realidad, están verdaderamente pensando en la colectividad, como las incluidas en la regulación europea sobre adjudicación de contratos públicos. Un expediente adicional consigue reducir muchísimo el efectivo alcance de la teoría de la norma tuitiva. Se dice que, al valorar si una norma es judicialmente exigible (esto es, si atribuye o no un derecho público subjetivo), deben ponderarse siempre las "directrices normativas internas" que la ley recibe del régimen constitucional de los derechos fundamentales. Como consecuencia de ello, se afirma, en las relaciones bipolares entre el ciudadano y el Estado, hay siempre derechos subjetivos. En particular, el reconocimiento constitucional de la libertad general (art. 2.1 LF) impondría que el ciudadano tenga siempre un derecho público subjetivo a exigir el cumplimiento de las obligaciones administrativas que afectan al ejercicio de potestades limitativas o de gravamen. Las regulaciones de prestaciones públicas serían también justiciables (esto es, atributivas de derechos) porque están conectadas con derechos fundamentales (asistencia social). Respecto de las relaciones multipolares, se dice que la cuestión es muy compleja, pero insistiendo en que debe tenderse al reconocimiento de cada vez más derechos públicos subjetivos como consecuencia de los derechos fundamentales (p. ej., en materia de urbanismo y planificación) y de la vocación individualista atribuida al ordenamiento de la Unión Europea (Derecho de la competencia y de la adjudicación de contratos públicos). Explican con detalle (y promueven abiertamente) la tendencia a reducir el juego de la teoría de la norma protectora: Armin von BOGDANDY y Peter Michael HUBER, "Estado, Administración y Derecho Administrativo en Alemania", en A. von BOGDANDY y O. MIR PUIGPELAT (coords.), El Derecho administrativo en el espacio jurídico europeo, Tirant lo Blanch, Valencia, 2013, pp. 107-116; ARNOLD (2014: 63-66). En cambio, Eberhard SCHMIDT-ASSMANN [La teoría general del Derecho administrativo como sistema, Marcial Pons, 2003, pp. 83-91] se muestra más en línea con el planteamiento decimonónico al rechazar un entendimiento expansivo de la eficacia subjetivadora de los derechos fundamentales, lo que conecta con su reivindicación de una "nueva" Ciencia del Derecho Administrativo volcada a la eficacia administrativa más que a las garantías individuales.

92 Carmen CHINCHILla MARÍN, "Dos grandes momentos en cien años de Derecho administrativo: La década de los cincuenta y la Constitución de 1978", El Derecho español en el siglo XX, Marcial Pons, Madrid, 2000, pp. 34-35.

93 NIETO GARCÍA (1986), Estudios históricos sobre Administración y Derecho administrativo, INAP, Madrid, 1986, pp. 8-9 
mismos postulados iusnaturalistas que influyeron sobre el constitucionalismo europeo se proyectaron así directamente sobre el Derecho administrativo español a través de la legislación y la jurisprudencia, sin pasar previamente por una Constitución.

De entre las múltiples reformas, destaca particularmente la Ley de la jurisdicción contencioso-administrativa de 1956. Favoreció la renovación "espectacular" de buena parte de las estructuras del Derecho administrativo ${ }^{94}$. El contencioso-administrativo, configurado ya como un orden jurisdiccional más, integrado por magistrados independientes, pero especializado en la materia administrativa, empezó a proteger con normalidad al ciudadano frente a las extralimitaciones del poder. Sin embargo, no eran pocas las huellas de la antigua justicia administrativa objetivada, algunas directamente impuestas por el gobierno a los redactores del texto legal ${ }^{95}$. La ejecución de sentencias seguía correspondiendo al propio "órgano que hubiere dictado el acto o disposición objeto del recurso" (art. 103). El recurso contencioso-administrativo debía dirigirse necesariamente contra una resolución administrativa previa e interponerse en un breve plazo (arts. 37, 52, 58). La Ley seguía dispensando una protección judicial menor, reducida a la anulación del acto ilegal, a quien solo pudiera esgrimir "intereses" [arts. 28.1 a) y 41]; las medidas de restablecimiento pleno eran solo para el titular de un "derecho derivado del ordenamiento" [arts. 28.1 a) y 42]. El interés legitimador que daba acceso al proceso debía ser "directo" [art. 28.1 a)]. Algunos actos seguían excluidos de la vía contencioso-administrativa: los dictados en función de policía sobre la prensa, la radio y la cinematografía; relativos a ascensos y recompensas en el ámbito militar; y otros indicados por la ley, como el acuerdo de necesidad de ocupación a los efectos de la expropiación forzosa (art. 40). Y solo las entidades públicas podían impugnar los reglamentos, excluyéndose respecto de ellos, por tanto, la legitimación individual [art. 28.1 b)].

El concepto clásico de interés legítimo, como negación del derecho subjetivo (y, por ende, de la protección judicial plena) pudo aún leerse en los estudios de Derecho administrativo. Sobresalen los de GARRIDO FALLA ${ }^{96}$ y GARCÍA-TREVIJANO FOS $^{97}$. El primero defendía que el interés legítimo es una posición subjetiva menor

${ }^{4}$ Así lo afirmó tempranamente Eduardo GARCÍA DE ENTERRÍA, "La interdicción de la arbitrariedad en la potestad reglamentaria”, RAP, núm. 30, 1959, pp. 131-166 (p. 151).

95 Se refiere a ello Jesús GONZÁLEZ PÉREZ, "Evolución de la legislación contencioso-administrativa”, RAP, núm. 150, 1999, pp. 209-238 (p. 223).

96 Ya en la primera edición de su Tratado de Derecho Administrativo de 1958. He manejado Fernando GARRIDO FALLA, Tratado de Derecho Administrativo, vol. I, Parte General, 7. a ed., Centro de Estudios Constitucionales, Madrid, 1980, pp. 412-418; id., Tratado de Derecho Administrativo, vol. III, La justicia administrativa, Tecnos, Madrid, 2001, pp. 34-36. El autor abordó también la cuestión del interés legítimo (y la distinción guicciardiana entre normas de acción y relación) en: "La Administración y la Ley", RAP, núm. 3, 1951, pp. 407-434; (1952: 157-174); "Las tres crisis del derecho público subjetivo", Estudios dedicados al Profesor García Oviedo con motivo de su jubilación, vol. I, Sevilla, 1954, pp. 177-217; y voz "Interés legítimo", en Nueva enciclopedia jurídica Seix, t. XIII, Seix, Barcelona, 1968, pp. 221-226.

${ }_{97}$ En la primera edición, de 1964, de su Tratado de Derecho Administrativo, t. I, Revista de Derecho Privado, Madrid. He manejado la tercera edición, de 1974 (pp. 558-576). 
(como la doctrina italiana), el segundo que es una condición de legitimación procesal (como en Francia), pero ambos estaban de acuerdo en lo fundamental. Partiendo de la aportación de GUICCIARDI, consideraban que las normas que imponen límites a las potestades administrativas no atribuyen derechos subjetivos correlativos, es decir, no confieren una posición de poder que pueda merecer plena protección en el proceso contencioso-administrativo. El ciudadano dispone solo de un interés que, en consonancia con lo dispuesto en la Ley jurisdiccional de 1956 [arts. 28.1 a) y 41], merece todo lo más la anulación del acto ilegal, pero no las medidas de restablecimiento pleno.

No obstante, este planteamiento quedó por completo desactivado por tres vías. En primer lugar, la inaplicación judicial pura y simple de las previsiones de la Ley de la jurisdicción contencioso-administrativa de 1956 que distinguían entre el interés directo y el derecho subjetivo para reservar al último las medidas de restablecimiento pleno. En segundo lugar, la identificación del interés legítimo con el concepto procesal de interés para accionar o recurrir -requisito indispensable para hacer valer un derecho subjetivo en el proceso-, que es un artificio característico del Derecho administrativo español precisamente a partir de los años cincuenta y del que no hay rastro en el panorama comparado, salvo en los ordenamientos americanos que se han dejado influir por el nuestro. Aceptar esta construcción supone descartar implícitamente, de modo consciente o no, que haya posiciones subjetivas menores merecedoras de una protección inferior. En tercer lugar, la teoría de las situaciones activas del administrado que el profesor GARCÍA DE ENTERRÍA elaboró antes de la aprobación de la Constitución a partir de la afectación singular del círculo vital propio como elemento basilar ${ }^{98}$. Siempre que la infracción de un vínculo normativamente impuesto a la administración acarrea este efecto, el principio de Estado de Derecho obligaría a interpretar que el ciudadano afectado ha sufrido la lesión de un derecho subjetivo correlativo. Por eso la "ley objetiva" puede "descomponerse" en tantos derechos subjetivos individuales como obligaciones pesan sobre la administración. La norma que obliga a la administración a motivar, a dar audiencia, a orientar su actividad hacia un concreto interés general, a sancionar solo las infracciones normativamente previstas, a no incurrir en arbitrariedad o a librar la licencia reglada atribuiría derechos subjetivos correlativos ${ }^{99}$.

La teoría de GARCÍA DE ENTERRÍA rendía tributo a la tradición al conservar la idea de que el interés legítimo es la posición subjetiva que permite exigir el cumplimiento de la norma jurídico-administrativa imbuida de una finalidad de interés general $y$, singularmente, la reguladora de la potestad administrativa. Sin embargo, el sentido de este concepto de interés legítimo era solo subrayar una característica de esta clase de derechos frente a los tradicionales del Derecho civil, pero no limitar

98 GARCÍA DE ENTERRÍA (1975: 427-448).

99 El profesor MODERNE se ha referido a la indicada descomposición del Derecho objetivo en derechos subjetivos concretos como elemento central de la teoría del interés legítimo como derecho subjetivo reaccional. Franck MODERNE, "Sotto il segno del soggettivismo giuridico (considerazioni sull'opera di Eduardo García de Enterría)”, Diritto pubblico, núm. 2, 2004, p. 688. 
las pretensiones de jurisdicción plena asociadas a los segundos, algo para lo que sí había servido históricamente aquella noción de "interés". El profesor parecía mantener ideas tradicionales también al afirmar que los "deberes objetivos" de la administración no llevan siempre asociados derechos subjetivos correlativos. Ahora bien, con ello no pretendía infraproteger al ciudadano enfrentado a la administración en estado de mando. Quería solo subrayar que únicamente ante la doble circunstancia de que la administración haya incumplido una obligación y de que el ciudadano haya sufrido por ello un concreto perjuicio, surge el interés legítimo como posición jurídico-subjetiva tutelable, es decir, como derecho subjetivo (atípico) que permite exigir judicialmente el cumplimiento de la legalidad y la puesta en marcha de las medidas necesarias para recomponerla. Por eso acaba afirmando que, en realidad, el Derecho administrativo objetivo puede descomponerse en tantos derechos subjetivos como límites normativamente impuestos a la administración.

La tesis de que estos derechos subjetivos son reaccionales, esto es, que surgen en el instante mismo en que hay incumplimiento lesivo del Derecho objetivo puede leerse en otros estudiosos con relación a supuestos concretos o al conjunto del ordenamiento (SATTA, en Italia ${ }^{100}$; ROUBIER, en Francia ${ }^{101}$ ). A mi juicio, su formulación en España obedeció a la funcionalidad práctica que atesoraba: permitía conciliar la tradición negadora del derecho subjetivo a la legalidad de la actuación administrativa con la afirmación del derecho subjetivo como posición activa que merece plena protección judicial cada vez que un ciudadano sufre las extralimitaciones del poder. En líneas generales, la doctrina española actual identifica en esta idea sobre el momento en que surge el derecho subjetivo el aspecto central y más discutible de la teoría de GARCÍA DE ENTERRÍA. A mi modo de ver, tal aspecto era, en realidad, secundario. Las consecuencias fundamentales derivadas de afirmar que el ciudadano es titular de derechos (acción, igualdad de armas procesales y protección plena) no cambian estrictamente según que se entienda que tales derechos surgen del Derecho administrativo en abstracto o del incumplimiento lesivo en concreto. Lo verdaderamente relevante es que la tesis de GARCÍA DE ENTERRÍA no dejaba espacio a posiciones activas secundarias que, por razón del interés general, no pudieran acceder a la jurisdicción o merecieran menos protección que el derecho subjetivo.

Ciertamente, esta singular recreación no era un ejercicio intelectual de puro divertimento. GARCÍA DE ENTERRÍA la llevó a cabo para algo: desactivar el concepto legal de interés legítimo (arts. 28.2 y 42 de la Ley de la jurisdicción contencioso-administrativa de 1956), que era el de siempre. Al definir el interés legítimo como clase de derecho subjetivo, el autor pretendía pertrechar de argumentos a los jueces para proporcionar al primero el nivel de garantías que la ley reservaba al segundo. De modo que el autor opuso el interés legítimo como derecho subjetivo atípico o especial al derecho subjetivo típico o común no con el fin de asegurarle un tratamien-

100 Salvatore SATTA, "Interesse ad agire e legittimazione", Il Foro italiano, vol. 77, núm. 8, 1954, pp. 169-178.

101 Paul ROUBIER, Droit subjectifs et situations juridiques, Dalloz, Paris, 1963. 
to jurídico diferenciado, sino para todo lo contrario, esto es, para evitar el tratamiento jurídico diferenciado que le dispensaba efectivamente la ley. En realidad, la Ley de la jurisdicción contencioso-administrativa de 1956 no soportaba en modo alguno esta interpretación. Pero lo que importaba a GARCÍA DE ENTERRÍA no era la consistencia formal de la teoría, sino la tutela material del ciudadano. Su compromiso con las libertades, más que la estricta técnica jurídica, explica tanto la defensa del contencioso objetivo de intereses que realizó en 1951 (mediante la invocación del principio de legalidad en los términos del art. 17 del Fuero de los Españoles) como la reivindicación en 1975 del contencioso subjetivo de derechos (mediante la recreación del interés legítimo) ${ }^{102}$. El autor se apoyó en el expediente que mejor servía en cada momento para sortear las dificultades que el Derecho positivo planteaba a la protección del ciudadano enfrentado a la administración. De modo que este concepto de "interés legítimo" equivale al de Mario NIGRO en el Derecho italiano. Sus contenidos son muy distintos, pero ambos respondían no a razones estrictamente científicas, sino a la voluntad de introducir garantías en el contexto de un Derecho positivo que arrastraba el autoritarismo del siglo XIX retroalimentado con la crisis de la democracia liberal de principios del siglo siguiente. Se trataba de encubrir el verdadero significado que la ley asignaba al "interés legítimo", pura y simplemente.

Al definir el interés legítimo como clase de derecho subjetivo, GARCÍA DE ENTERRÍA ocultó su auténtico significado no solo al juez administrativo, sino también a la doctrina académica. Ello ha contribuido a que buena parte de los administrativistas españoles haya olvidado qué es el "interés legítimo": un concepto que, cumpliendo una formidable función práctica en el proceso de afirmación de las garantías individuales, surgió y se desarrolló siempre con un marcado carácter autoritario, radicalmente inconciliable con los presupuestos axiológicos del Estado de Derecho. En la actualidad, la Constitución garantiza siempre la tutela judicial efectiva frente al incumplimiento lesivo de la norma jurídico-administrativa (art. 24). A su vez, la vigente Ley reguladora de la jurisdicción contencioso-administrativa de 1998 ha regulado en consonancia un proceso subjetivo y sustancialmente paritario destinado a proporcionar protección plena. Sin embargo, en parte como consecuencia de aquella bienintencionada manipulación conceptual, hay la opinión generalizada de que el interés legítimo es un concepto técnico nacido para enriquecer la teoría de las situaciones jurídico-subjetivas del Derecho administrativo e, incluso, que está en condiciones de canalizar más tutela que su antagonista clásico, el derecho subjetivo ${ }^{103}$. Al ensombrecerse su verdadero significado, el interés legítimo ha dejado de asociarse a la

102 "El principio objetivo de mantenimiento del Derecho por los órganos públicos" consagrado en el artículo 17 del Fuero de los españoles "está imponiendo la necesidad de un sistema contencioso-administrativo progresivo": Eduardo GARCÍA DE ENTERRÍA, "Sobre un texto refundido de la legislación contencioso-administrativa”, RAP, núm. 6, 1951, pp. 279-288 (p. 287). El autor admitió después que su crítica era "circunstanciada": Eduardo GARCÍA DE ENTERRÍA, Democracia, jueces y control de la Administración, 3. a ed., Civitas, Madrid, 1999, p. 38.

103 Véase, por ejemplo, Ana Belén GÓMEZ DÍAZ, La legitimación en el proceso contencioso-administrativo, Iustel, Madrid, 2014. 
infraprotección resultante de la afirmada prevalencia del interés general, extendiéndose la creencia de que todavía hoy tiene que existir como posición de poder.

La teoría del derecho subjetivo reaccional ha cerrado formalmente la discusión espańola de las situaciones activas del administrado. A su vez, nadie cuestiona sus efectos prácticos en el sentido de que todos están de acuerdo en que el perjudicado por el incumplimiento lesivo de la norma jurídico-administrativa merece protección judicial plena. Sin embargo, ello no se explica por referencia al derecho subjetivo correlativo a la obligación que esa norma impone al poder de la administración. Los profesores citan la teoría con mucha frecuencia, normalmente para darla por buena, pero, en realidad, no han proyectado el concepto de derecho subjetivo sobre la parte general del Derecho administrativo ni lo aplican en la parte especial ${ }^{104}$. No ha calado tampoco en el Derecho judicial ${ }^{105}$. En fin, el "interés legítimo" opera como "interés para accionar", esto es, como una exigencia procesal de afectación singular, condición necesaria en todos los ordenamientos para hacer valer derechos subjetivos. La particularidad espańola es que se dice que el interés legítimo, así entendido, es una situación jurídico-subjetiva paralela o distinta del derecho subjetivo. Semejante artificio tenía sentido en el contexto de la Ley jurisdiccional de 1956; servía para desdibujar el concepto legal de interés y la consecuente infraprotección judicial. Dentro del sistema constitucional de 1978, esta ficción no es ya precisa para asegurar un régimen de tutela judicial efectiva. Sin embargo, al igual que los expedientes funcionalmente equivalentes de otros sistemas jurídicos, subsiste por inercia tanto en la jurisprudencia como en la doctrina.

\subsection{La regulación de los derechos: el derecho subjetivo como interés jurídicamente protegido}

El nuevo constitucionalismo reafirmó la libertad como derecho anterior al Estado, pero ello en modo alguno conllevaba un credo individualista. Excluyó sin paliativos el transpersonalismo, las ideologías que degradan al hombre a la condición de mero instrumento del poder, proclamando que "el Estado existe para el hombre, no el hombre para el Estado" ${ }^{106}$, pero sin establecer positivamente una concepción del

104 Hay excepciones: Margarita BELADIEZ ROJO, Validez y eficacia de los actos administrativos, Marcial Pons, Madrid, 1994, pp. 155-156; MEDINA ALCOZ (2016); Dolores UTRILLA FERNÁNDEZ-BERMEJO, "La relación jurídica en el sistema de Derecho administrativo", Revista de Derecho público: teoría y método, vol. 2, 2020, pp. 73-118. Bajo el signo del Derecho alemán: Alfredo GALLEGO ANABITARTE, Derecho general de la organización, IEA, Madrid, 1971, pp. 263 y ss.; id., "Función ejecutiva, actuación administrativa y discrecionalidad”, Cuadernos de la Facultad de Derecho, vol. 9, 1984, p. 107; Luciano PAREJO ALFONSO, "Las bases constitucionales del Derecho administrativo (I)", en Manual de Derecho Administrativo, vol. 1, 4. ${ }^{a}$ ed., Ariel, Barcelona, 1996, p. 67; Alejandro HUERGO LORA, Las pretensiones de condena en el contencioso-administrativo, Aranzadi, Elcano, 2000, pp. 461 y ss.; Silvia DÍEZ SASTRE, La tutela de los licitadores en la adjudicación de contratos públicos, Marcial Pons, Madrid, 2012, especialmente pp. 69-102, 105-118.

105 Ampliamente: MEDINA ALCOZ (2016: 181-216, 243-251).

106 Tal era el apartado primero del primer artículo del borrador de Constitución alemana elaborado por la Convención Herrenchiemsee. Tal como explica WAHL (2013: 39-40), esta fórmula, aunque 
mundo de entre las muchas compatibles con la dignidad personal. Proporcionaba un marco de límites dentro del cual el juego democrático podía alumbrar políticas de muy diverso signo ${ }^{107}$. Más aún, la intervención estatal en favor de la igualdad de oportunidades se afirmó como obligación estatal irrenunciable (p. ej., art. 3 de la Constitución italiana). El Estado es social y democrático, no solo de Derecho (art. 20 de la Ley fundamental de Bonn, art. 1.1 de la Constitución española). De hecho, los Estados de la Europa occidental, con el consenso de la socialdemocracia y la democracia cristiana, intervinieron fuertemente en la economía para promover positivamente la igualdad material y asegurar el bienestar general, sin contestar por ello el régimen capitalista. Se trata del denominado Estado de Bienestar.

De modo que, de acuerdo con el nuevo constitucionalismo, el legislador está autorizado a asignar derechos conforme a los fines o intereses que a su modo de ver incrementan el bienestar social. El poder público puede configurar, restringir o suprimir el derecho de uno no solo para garantizar el libre ejercicio del derecho de otro, sino también para promover los más variados fines, bienes u objetivos. Naturalmente, los derechos no eran los "artificios" puros del iuspositivismo decimonónico, artefactos que el Estado había podido regular, dar o quitar a placer: el Derecho internacional de los derechos humanos y las normas constitucionales pusieron barreras (de Estado de Derecho) a medidas de este tipo (reserva de ley, límites a la legislación extraordinaria de urgencia, prohibición de retroactividad de las disposiciones restrictivas, proporcionalidad, indemnización), pero menos que el pensamiento liberal de finales del siglo XviI y principios de la centuria siguiente. Decayó el fundamento del Derecho objetivo (y, por tanto, del mismo Estado) subyacente a la doctrina del derecho subjetivo como autonomía de la voluntad. En suma, el Derecho objetivo sirve no solo para armonizar la libertad de uno con la de otro, sino también para incrementar el bienestar social conforme a fines o intereses políticamente seleccionados, aunque ello implique privilegiar a un individuo en detrimento de otro.

Hace tiempo que la doctrina académica ha aislado el fenómeno en lo atinente al derecho de propiedad ${ }^{108}$. El Estado puede negarlo o restringirlo no solo para evitar la perturbación del libre disfrute del derecho de otro, sino además para conseguir mayor bienestar social. Por eso el régimen del derecho de propiedad no es ya necesariamente expresión de la igualdad intrínseca de los hombres en tanto que seres dotados de dignidad; su contenido y su misma existencia dependen de finalidades públicas

no llegó a vincular como tal, surtió efecto; "tocó el nervio de la época y fue captada en su intención directiva". Ciertamente, "esta idea de fondo se halla inserta en la tradición, vieja de siglos, del Derecho racional y la Ilustración. Pero en el contexto de la época posterior a 1949 el mensaje contenido en ese enunciado quemaba como si acabara de ser descubierto". Sobre el concepto de transpersonalismo: Luis RECASENS SICHES, Tratado general de Filosofía del Derecho, Porrua, 3. a ed., México D. F., 1965, pp. 497-511.

107 Manuel GARCÍA-PELAYO, "Consideraciones sobre las cláusulas económicas de la Constitución", Estudios sobre la Constitución Española de 1978, Libros Pórtico, Zaragoza, 1979, pp. 27-53 (pp. 29, 50-53).

108 Baste la cita de una obra clásica: Stefano RODOTÀ, El terrible derecho: estudios sobre la propiedad privada, Civitas, Madrid, 1987. 
variables, los que en cada momento y lugar identifiquen políticamente los poderes públicos. De ahí que se diga que el derecho de propiedad cumple una función social y que su contenido es políticamente variable, esto es, estatutario: "en el marco del Estado social (art. 1.1 CE), el legislador está autorizado a negar pura y simplemente el derecho de propiedad por razones de utilidad pública e interés general —con los límites que impone el art. 33.3 CE—o, sin llegar hasta este extremo, a restringirlo para ajustar su contenido a los más variados objetivos colectivos (arts. 33.2 y 128.1 $\mathrm{CE}$ ) con la consiguiente generación de 'diferentes tipos de propiedades dotadas de estatutos jurídicos diversos' " (STC 154/2015, de 9 de julio, FJ 4, citando las SSTC 37/1987, de 26 de marzo, FJ 2, y 204/2004, de 18 de noviembre, FJ 5).

Ello no es algo exclusivamente característico del derecho de propiedad. La mayor parte de los derechos provienen de una legislación ordinaria que los atribuye, quita o configura para satisfacer finalidades que no son ya, simplemente, la evitación de agresiones recíprocas. Se trata a la postre de derechos de contenido estatuario cuya regulación responde a funciones sociales. Esto es evidente en el Derecho administrativo prácticamente desde sus orígenes, pero también hace ya algún tiempo en el Derecho privado. Los principios pro infantia, pro consumatore y pro operario de los Derechos de familia, consumo y trabajo, respectivamente, ejemplifican cómo el Derecho privado reparte y configura derechos subjetivos para proteger determinados intereses o fines sin adoptar ya reglas necesariamente neutrales o destinadas a facilitar simplemente que cada cual persiga libremente sus propios objetivos. Otro ejemplo: el Derecho de la competencia impulsa activamente el libre mercado por razones de efficiency, no de fairness; no para realizar el harm principle, sino para incrementar la overall wealth, esto es, por las ganancias que presumiblemente resultan para el conjunto de la ciudadanía ${ }^{109}$.

De modo que las finalidades públicas, esenciales en la teoría de los derechos ajustada a la lógica autoritaria del siglo xix y retroalimentada en el entorno antidemocrático de principios del siglo siguiente, siguieron siéndolo dentro del marco constitucional imperante a partir de la Segunda Guerra Mundial, solo que de muy distinta manera. Los objetivos colectivos jugaban entonces sobre todo en el plano del poder judicial, garantizando a la administración esferas de inmunidad jurisdiccional. Debido a ellos, el particular carecía de derechos subjetivos correlativos a los límites normativos que afectaban al ejercicio de las potestades administrativas y, con ello, de la posibilidad de exigir judicialmente la protección plena frente a la administración incumplidora de sus obligaciones. Después esas finalidades públicas han pasado a intervenir exclusivamente en el plano del poder político. El Estado tiene amplísimas (aunque no ilimitadas) posibilidades para distribuir derechos conforme a finalidades públicas (intereses generales) cuando opera como poder político (puede atribuir, quitar y configurar derechos), pero no cuando opera como poder judicial (debe garantizar la protección judicial plena frente al incumplimiento de las obligaciones de la

109 David J. GERBER, "Constitutionalising the Economy: German Neoliberalism, Competition Law and the 'New Europe", The American Journal of Comparative Law, núm. 42, 1994, pp. 25-84. 
administración entendidas como derechos individuales correlativos con independencia de la finalidad normativa). El Estado se ajusta en parte al concepto de IHERING cuando atribuye derechos, pero se acomoda al de SAVIGNY cuando corresponde determinar cuáles son los efectivamente establecidos a los efectos de la justiciabilidad.

La fuerte penetración de la lógica finalista del interés general en el plano de la regulación pone de relieve hasta qué punto resulta hoy imposible mantener en el plano de la protección que las obligaciones normativamente impuestas son derechos subjetivos correlativos solo si contemplan intereses privados. No es ya que ello sea incompatible con el profundo significado del reconocimiento internacional y constitucional de la dignidad humana en su proyección sobre el Derecho administrativo establecido; un reconocimiento al que repugna que los gobiernos y los parlamentos puedan decidir sobre la justiciabilidad de las normas que ellos predisponen como límites a la acción administrativa. Es que se hace depender la tutela judicial efectiva de los derechos de operaciones interpretativas que, si son de suyo complejas, llegan a ser completamente artificiosas en el contexto de un ordenamiento jurídico que interviene sobre prácticamente todas las dimensiones de la vida en función de lo que conviene al interés general. Distinguir las normas (y el grado de protección frente a su incumplimiento) en función de que protejan intereses generales o particulares supone en cierto modo desconocer que han desaparecido ya aquellas fronteras que separaban tajantemente el interés general del interés particular, el Derecho administrativo del Derecho civil, lo público de lo privado, el Estado de la sociedad.

\section{CONCLUSIONES}

Comprender el problema del derecho subjetivo es fundamental para entender plenamente los orígenes y las trasformaciones fundamentales del Derecho administrativo a lo largo de los últimos doscientos años. La noción de derecho subjetivo era central en la cultura jurídica desde al menos el siglo xvi. El surgimiento del Derecho administrativo evidenció el tránsito del derecho subjetivo al Derecho objetivo, esto es, de un Derecho volcado al hombre, eje del pensamiento iusnaturalista, a un ordenamiento volcado a la comunidad, entendida como todo social (el interés general), capital en las nuevas ideologías. Solo después de la Segunda Guerra Mundial empezó a edificarse en España y el conjunto de Europa un Derecho administrativo subjetiva$d o$, que coloca en un lugar central, no solo el interés general, sino también la libertad individual.

A lo largo del siglo XIx, los sistemas europeos de Derecho público desarrollaron con diferentes matices una misma teoría sobre el derecho subjetivo. Se apoyaban en la finalidad pública de la norma jurídico-administrativa para construir el concepto de derecho "secundario" ("administrativo", "imperfecto") o simple "interés" y negar con ello el auténtico derecho subjetivo (y, por tanto, la tutela judicial plena) del ciudadano enfrentado al poder de la administración. Tal teoría, nutrida de rudimentos del Estado absoluto y del liberalismo conservador, sirvió a la construcción del Estado adminis- 
trativo. Se robusteció con la crisis de la democracia liberal de principios de siglo xx. Ciertamente, la consolidación de un régimen de garantías individuales que contrapesara la construcción de un Estado sin precedentes, muy amplio y hegemonizado por la administración, empezó a realizarse efectivamente dentro de (y en parte gracias a) la señalada teoría. Permitía transitar sin traumatismos hacia un sistema tuitivo, haciendo pasar la protección del ciudadano por protección del interés general y de la legalidad administrativa objetiva. Pero estas ventajas prácticas no deben ocultar los déficits de tutela y que el Derecho administrativo hablaba invariablemente el lenguaje del Derecho objetivo y el control (principio de la legalidad en clave objetiva) más que el lenguaje del derecho subjetivo y la protección (principio de legalidad en clave subjetiva). Este último había dominado desde al menos el siglo XVI, pero quedó caracterizado entre mediados del siglo XIX y principios del siguiente como idioma específico del Derecho privado y de las relaciones jurídico-administrativas horizontales.

Tras la Segunda Guerra Mundial, los sistemas europeos de Derecho administrativo asistieron, también con diversas formas e intensidades, a la revalorización del derecho subjetivo (y, por tanto, de la protección judicial plena) con la consiguiente relativización de aquel autoritarismo originario. La protección (judicial) frente a la administración incumplidora de sus obligaciones se ajustó al viejo lenguaje civilista y liberal del derecho subjetivo como autonomía de la voluntad. El nuevo constitucionalismo subjetivó el Derecho administrativo y el proceso contencioso-administrativo. La norma que obliga a la administración pasó a ser, sencillamente, el derecho subjetivo de quien resulta perjudicado por su incumplimiento. El lenguaje del derecho y la protección volvió a generalizarse, dejando de ser patrimonio exclusivo de civilistas. No obstante, esta trasformación se emprendió sin prescindir del marco conceptual autoritario del viejo Derecho administrativo. De ahí que hayan subsistido los antiguos significantes (interés legítimo, Schutznormtheorie) y que los diversos sistemas hayan desarrollado teorías sobre las situaciones activas aparentemente distintas.

En España, la doctrina administrativista actual asocia el "interés legítimo" a un alto grado de protección judicial, como si hubiera surgido históricamente para proporcionar niveles de tutela imposibles dentro del marco conceptual de los derechos subjetivos. Ha desarrollado en paralelo una cierta animadversión hacia el "derecho subjetivo", como si fuera en parte responsable de las dificultades que ha presentado históricamente proteger al ciudadano frente a las extralimitaciones del poder. Se cree que uno de los principales defectos de la justicia administrativa armónica o judicializada era, precisamente, el cierre del recurso a quien no pudiese exhibir derechos subjetivos. Estas creencias no se ajustan a la realidad. Proyectan sobre el pasado una percepción moderna, la visión positiva que hoy tenemos del "interés legítimo", como figura que, según se entiende, cataliza más tutela que el derecho subjetivo. El problema de nuestra justicia administrativa decimonónica fue, en realidad, no que protegiese solo derechos, sino todo lo contrario: que negaba el derecho subjetivo (cuando impedía el control de los elementos reglados de las potestades discrecionales) o lo transformaba en una posición de segunda categoría (frente a la potestad reglada, al permitir un control sin igualdad de armas y escasos remedios tutelares). En suma, 
nuestro "derecho subjetivo de carácter administrativo" equivalía en gran medida al interés francés (condición de legitimación que da acceso a la jurisdicción objetiva de anulación), al interés legítimo italiano (posición subjetiva distinta del derecho subjetivo protegida con los limitados remedios de la justicia administrativa) y al interés alemán (situación carente de toda protección judicial).

Nuestro Derecho administrativo sigue manejando la expresión "interés legítimo" más, incluso, que otros ordenamientos, pero, en realidad, desechó antes y más rotundamente su significado originario. Al prescindir del objetivo de la norma y afirmar la jurisdicción plena ya en los años cincuenta del siglo pasado, anticipó de hecho la teoría del derecho subjetivo a la que acabaron ajustándose los ordenamientos administrativos de nuestro entorno. El "interés legítimo" ha devenido así un continente vacío, un fósil, un vestigio, la huella de algo que ha desaparecido. Del "interés legítimo" queda solo el nombre. El sistema jurídico conserva el significante, pero le ha hurtado su significado histórico.

El interés legítimo era un problema real y muy serio: la inmunidad (total o parcial) de la administración fundada en la prevalencia de las finalidades públicas que persigue el Derecho administrativo. El problema ha pasado a ser, simplemente, atribuirle nuevo significado a la vista de que la denominación luce en la Constitución y las leyes sin su contenido originario. Se trata pues de un problema verbaly, en cuanto tal, menos relevante. Lo importante, al menos a los efectos de este estudio, es que el interés legítimo no opera en la práctica como una posición subjetiva paralela a (o distinta de) el derecho subjetivo. Funciona como un requisito procesal para hacer valer derechos subjetivos. Me refiero a la "afectación singular" o "interés en la acción", es decir, a la exigencia de que el recurrente arriesgue algo verdaderamente para que pueda hacer valer una norma ante la jurisdicción.

\section{BIBLIOGRAFÍA}

Fermín ABELLA Y BLAVE, Manual teórico-práctico de lo contencioso-administrativo y del procedimiento especial en los asuntos de hacienda, El consultor de los ayuntamientos y de los juzgados municipales, Madrid, 1882.

Antonio ALCALÁ GALIANO, Lecciones de Derecho politico constitucional, Boix, Madrid, 1843.

Antonio ALCÁNTARA PÉREZ y Juan MORALES SERRANO, Tratado de las competencias y de la autorización para procesar a los empleados públicos, 2 t., Imprenta de J. E. Morete, 1866.

Santos ALFARO Y LAFUENTE, Jurisprudencia del Consejo de Estado sobre la procedencia de las demandas administrativas, Imprenta de la Revista de legislación á cargo de Julián Morales, Madrid, 1867.

—, Tratado completo de lo contencioso-administrativo, Imprenta Nicolás González, Madrid, 1875.

-, Lo contencioso-administrativo. Su materia, sus tribunales, sus procedimientos, Librería universal de Córdoba y Compañía, Madrid, 1881.

Sabino ÁLVAREZ-GENDÍN Y BLANCO, Manual de Derecho administrativo, Librería General, Zaragoza, 1941.

—, "Acción popular y recursos administrativos contra los actos de la Administración local”, RAP, núm. 11, 1953, pp. 221-267.

Hannah ARENDT, Los origenes del totalitarismo, Taurus, Madrid, 1998 (original de 1951). 
Reiner ARNOLD, "Legittimazione a ricorrere e situazioni soggettive nell'ordinamento tedesco", en Colloquio sullinteresse legittimo. Atti del Convegno in memoria di Umberto Pototschnig, Milano, 19 aprile 2013, Jovene, Napoli, 2014, pp. 57-66.

Margarita BELADIEZ ROJO, Validez y eficacia de los actos administrativos, Marcial Pons, Madrid, 1994.

Andrés BETANCOR RODRÍGUEZ, El acto ejecutivo, CEPC, Madrid, 1992.

Armin von BOGDANDY, "El Derecho administrativo en el Espacio jurídico europeo: perspectivas de una disciplina”, en A. von BOGDANDY y O. MIR PUIGPELAT (coord.), El Derecho administrativo en el espacio jurídico europeo, Tirant lo Blanch, Valencia, 2013, pp. 293-338.

Armin von BOGDANDY y Peter Michael HUBER, "Estado, Administración y Derecho Administrativo en Alemania", en A. von BOGDANDY y O. MIR PUIGPELAT (coord.) El Derecho administrativo en el espacio jurídico europeo, Tirant lo Blanch, Valencia, 2013, pp. 107-116.

Cristóbal BORDIÚ Y GÓNGORA, Del Consejo Real como elemento del Gobierno constitucional, Imprenta de la Compañía de Impresores y Libreros, Madrid, 1846.

Ottmar BÜHLER, Die subjecktiven öffentlichen Rechte und ihr Schutz in der deutschen Verwaltungsrechtsprechung, W. Kohlhammer, Berlin, 1914.

José María CABALLERO Y MONTES, Lo contencioso-administrativo, I, Escar, Zaragoza, 1902.

Louis CABANTOUS, Répetitions Écrites sur le droit public et administratif, 4. ${ }^{\mathrm{a}}$ ed., A. Maresco Ainé, Paris, 1867.

Sabino CASSESE, Derecho administrativo: Historia y futuro, Global Law Press, Sevilla, 2014.

Carmen CHINCHILLA MARÍN, "Dos grandes momentos en cien años de Derecho administrativo: La década de los cincuenta y la Constitución de 1978", El Derecho español en el siglo XX, Marcial Pons, Madrid, 2000.

Bartolomé CLAVERO SALVADOR, Happy Constitution. Cultura y lengua constitucionales, Trotta, Madrid, 1997.

Chiara CUDIA, Funzione amministrativa e soggettività della tutela. Dall'eccesso di potere alle regole del rapporto, Giuffrè, Milano, 2008.

José DİAZ UFANO Y NEGRILLO, Tratado teórico-práctico de materias contencioso-administrativas en la peninsula y ultramar, M. Minuesa, Madrid, 1866.

Silvia DÍEZ SASTRE, La tutela de los licitadores en la adjudicación de contratos públicos, Marcial Pons, Madrid, 2012.

Albert Venn DICEY, Introduction to the Study of the Law of the Constitution, reimpresion de la 8. a ed., coord. Roger E. Michener, Liberty Fund, Indianapolis, 1982 (original de 1915).

Gabriel DOMÉNECH PASCUAL, La invalidez de los reglamentos, Tirant lo Blanch, Valencia, 2002.

Léon DUGUIT, Les transformations du droit public, Librairie Armand Colin, Paris, 1921.

-, Le droit social, le droit individuel et la transformation de L'État. Conferénces faites a L'École des Hautes Ėtudes Sociales, 3. a ed., Librairie Félix Alcan, Paris, 1922.

Antonio María FABIÉ ESCUDERO, Comentario de la Ley para el ejercicio de la jurisdicción contenciosoadministrativa, Imprenta de la Revista de Legislación, Madrid, 1889.

Juan Ramón FERNÁNDEZ TORRES, La formación histórica de la jurisdicción contencioso-administrativa (1845-1868), Civitas, Madrid, 1998.

Recaredo FERNÁNDEZ DE VELASCO, La "acción popular" en el Derecho administrativo, Reus, Madrid.

—, El acto administrativo (exposición doctrinal y estudio del Derecho español), prólogo de M. Hauriou, Victoriano Suárez, Madrid, 1929.

Leonardo FERRARA, Diritti soggettivi ad accertamento amministrativo, Cedam, Padova, 1996.

—, Dal giudizio di ottemperanza al processo di esecuzione: la dissoluzione del concetto di interesse legittimo, Giuffrè, Milano, 2003.

Norbert FOULQUIER, Les droits subjectifs des administrés. Emergence d'un concept en droit administratif français du XIXè au XXè siècle, Dalloz, Nouvelle Bibliothèque de thèses, t. 25, Paris, 2003.

-, "Lanalyse du discours juridique: le concept de droit subjectif en droit administratif", en Sur la portée sociale du droit. Usages et légitimité du registre juridique, PUF, 2005. 
Patrick FRAISSEIX, "La subjectivisation du droit administratif”, Les petites affiches, núm. 207, 2004, pp. 12-16.

Alfredo GALLEGO ANABITARTE, Derecho general de la organización, IEA, Madrid, 1971.

José GALLOSTRA Y FRAU, Lo contencioso-administrativo, Imprenta y fundición Manuel Tello, Madrid, 1881.

Carlos GARCÍA OVIEDO, "El recurso contencioso-administrativo en la nueva Constitución española, Revista de Derecho Público, 1932, pp. 298-299.

Eduardo GARCÍA DE ENTERRÍA MARTÍNEZ-CARANDE, "Sobre un texto refundido de la legislación contencioso-administrativa”, $R A P$, núm. 6, 1951, pp. 279-288.

—, "La interdicción de la arbitrariedad en la potestad reglamentaria", RAP, núm. 30, 1959, pp. 131166.

—, "Sobre los derechos públicos subjetivos", REDA, núm. 6, 1975, pp. 427-448.

—, Democracia, jueces y control de la Administración, 3.a ed., Civitas, Madrid, 1999.

—, Problemas del Derecho público al comienzo de siglo, Civitas, Madrid, 2001.

-, Las Transformaciones de la Justicia Administrativa: De excepción singular a la plenitud jurisdiccional. ¿Un cambio de paradigma?, Thomson/Civitas, Cizur Menor, 2007.

Manuel GARCÍA-PELAYO Y ALONSO, "Consideraciones sobre las cláusulas económicas de la Constitución”, Estudios sobre la Constitución Española de 1978, Libros Pórtico, Zaragoza, 1979, pp. 2753.

—, Las transformaciones del Estado contemporáneo, Alianza, Madrid, 1981.

José Antonio GARCÍA-TREVIJANO FOS, Tratado de Derecho Administrativo, t. I, 3.a ed., Revista de Derecho Privado, Madrid, 1974.

Fernando GARRIDO FALLA, "La Administración y la Ley", RAP, núm. 3, 1951, pp. 407-434.

—, "El interés para recurrir en agravios", RAP, núm. 9, 1952, pp. 157-174.

—, "Las tres crisis del derecho público subjetivo", Estudios dedicados al Profesor García Oviedo con motivo de su jubilación, vol. I, Sevilla, 1954, pp. 177-217.

—, voz "Interés legítimo", en Nueva enciclopedia jurídica Seix, t. XIII, Seix, Barcelona, 1968, pp. 221 226.

—, Tratado de Derecho Administrativo, vol. I, Parte General, 7. a ed., Centro de Estudios Constitucionales, Madrid, 1980.

—, Tratado de Derecho Administrativo, vol. III, La justicia administrativa, Tecnos, Madrid, 2001.

José GASCÓN Y MARÍN, Las garantias jurídicas del ciudadano y la evolución del recurso contenciosoadministrativo, Madrid, 1917.

—, Derecho administrativo. Principios y legislación española, t. I, Doctrina general, 7. a ed., C. Bermejo, Madrid, 1941.

—, "Restablecimiento del recurso contencioso-administrativo", Revista de Estudios de la Vida Local, núm. 14, 1944, pp. 271-274.

David J. GERBER, "Costitutionalising the Economy: German Neoliberalism, Competition Law and the 'New Europe"', The American Journal of Comparative Law, núm. 42, 1994, pp. 25-84.

Rudolf von GNEIST, Lo Stato secondo il diritto ossia la giustizia nell'amministrazione politica, traducción de I. Artom, Zanichelli, Bologna, 1884 (original de 1879).

Ana Belén GÓMEZ DÍAZ, La legitimación en el proceso contencioso-administrativo, Iustel, Madrid, 2014.

Pedro GÓMEZ DE LA SERNA Y TULLY y Juan Manuel MONTALBÁN HERRANZ, Tratado académico-forense de los procedimientos judiciales, t. I, 3.a ed., D. F. Sánchez, Madrid, 1861.

Alfonso GONZÁLEZ CARMONA, La materia contencioso-administrativa: teoría, legislación vigente, jurisprudencia, Imprenta de Enrique Rubiños, Madrid, 1891.

Jesús GONZÁLEZ PÉREZ, "Evolución de la legislación contencioso-administrativa", RAP, núm. 150, 1999, pp. 209-238.

Santiago GONZÁLEZ-VARAS IBÁŃEZ, La jurisdicción contencioso-administrativa en Alemania, Civitas, Madrid, 1993.

Jaime GUASP DELGADO, “El 'derecho de carácter administrativo' como fundamento del recurso de contencioso", Revista de la Facultad de Derecho de Madrid, núm. 2, 1940, pp. 11-23. 
Enrico GUICCIARDI, "Concetti tradizionali e principii riconstruttivi nella giustizia amministrativa”, en Studi di giustizia amministrativa, Edit. Torinese, Torino, 1967 (original de 1937), pp. 1-23.

Maurice HAURIOU, Precis de droit administratif, 8.a ed., Sirey, Paris, 1914.

-, "La gestión administrativa", en Obra escogida, trad. J. A. Santamaría Pastor/S. Muñoz Machado, Instituto de Estudios Administrativos, Madrid, 1976 (original de 1899).

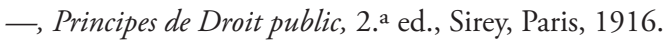

Reinhard HÖHN, Die Wandlung im staatsrechtlichen Denken, Hanseatische Verlagsanstalt, Hamburg, 1934.

Ernest Rudolf HUBER, Verfassung, Hanseatische Verlagsanstalt, Hamburg, 1937.

—, Verfassungsrecht des grossdeutschen Reiches, 2. ${ }^{\mathrm{a}}$ ed., Hanseatische Verlagsanstalt, Hamburg, 1939.

Alejandro HUERGO LORA, Las pretensiones de condena en el contencioso-administrativo, Aranzadi, Elcano, 2000.

Rudolf von IHERING, El espiritu del Derecho romano en las diversas fases de su desarrollo, Comares, Granada, 1998 (original de 1852-1865).

Georg JELLINEK, Sistema dei diritti pubblici subbiettivi, traducción italiana de la 2. ${ }^{\text {a }}$ ed. (1. ${ }^{\mathrm{a}}$ ed. de 1892), Libraria, Milano, 1912 (original de 1905).

Immanuel KANT, Introducción a la teoría del Derecho, CEPC, Madrid, 1978 (original de 1797).

John Maurice KELLY, Storia del pensiero giurico occidentale, Il Mulino, Bologna, 1997.

Otto KOELLREUTTER, Deutsches Verfassungsrecht, Junker und Dünnhaupt, Berlin, 1936.

Bruno KORNPROBST, La notion de partie et le recours pour excès de pouvoir, Librairie générale de droit et de jurisprudence, Paris, 1959.

Edouard LAFERRIÈRE, Traitè de la juridiction administrative et des recours contentieux, 2 vols., reimpresión prologada por R. Drago, LGDJ, 1989 (original de 1887).

Martin LOUGHLIN, Foundations of Public Law, Oxford University Press, Oxford, 2012.

Gonzalo MAESTRO BUELGA, "Los derechos públicos subjetivos en la historia del constitucionalismo espańol”, Revista de Derecho Político, núm. 41, 1996, pp. 119-175.

Manuel MALO DE MOLINA, Conferencias sobre lo contencioso-administrativo, pronunciadas en el Ateneo de Madrid en el curso de 1860 a 1861, Arcas y Sánchez, Madrid, 1861.

Isaac MARTÍN DELGADO, La ejecución subrogatoria de las sentencias contencioso-administrativas, Iustel, Madrid, 2006.

Luis MARTÍN REBOLLO, El proceso de elaboración de la Ley de lo contencioso-administrativo de 13 de septiembre de 1888, Instituto de Estudios Administrativos, Madrid, 1975.

Sebastián MARTÍN-RETORTILLO BAQUER, Alejandro Oliván: Reflexiones sobre su vida y su obra, Civitas, Madrid, 1997.

Hartmut MAURER, Derecho administrativo. Parte General, Marcial Pons, Madrid, 2011.

Otto MAYER, Derecho administrativo alemán, t. I (Parte general), Depalma, Buenos Aires, 1982 (original de 1895).

Luis MEDINA ALCOZ, Libertad y autoridad en el Derecho administrativo. Derecho subjetivo e interés legitimo: una revisión, Marcial Pons, Madrid, 2016.

—, Historia del Derecho administrativo español, Marcial Pons, Madrid, en prensa.

Franck MODERNE, "Sotto il segno del soggettivismo giuridico (considerazioni sull'opera di Eduardo García de Enterría)", Diritto pubblico, núm. 2, 2004, pp. 671-690.

Lodovico MORTARA, "Sulla classificazione degli atti amministrativi (d'impero e di gestione)", Giurisprudenza italiana, vol. I/1, 1899, pp. 549-552.

Alejandro NIETO GARCÍA, "Sobre la tesis de Parada en relación con los orígenes de lo contenciosoadministrativo", RAP, núm. 57, 1968, pp. 9-34.

—, Estudios históricos sobre Administración y Derecho administrativo, INAP, Madrid, 1986.

Mario NIGRO, Giustizia amministrativa, 6. ${ }^{\text {a }}$ d. revisada por E. Cardi y A. Nigro, Il Mulino, Bologna, 2002.

Riccardo ORESTANO, Azione, diritti soggettivi, persone giuridiche, Il Mulino, Bologna, 1978.

Andrea ORSI BATTAGLINI, "Attività vincolata e situazioni soggettive", Rivista trimestrale di diritto processuale, 1988, pp. 3 ss.

—, Alla ricerca dello Stato di diritto. Per una giustizia "non amministrativa", Giuffrè, Milano, 2005. 
José Ramón PARADA VÁZQUEZ, "Privilegio de decisión ejecutoria y proceso contencioso", RAP, núm. 55, 1968, pp. 65-112.

Luciano PAREJO ALFONSO, "Las bases constitucionales del Derecho administrativo (I)", en Manual de Derecho Administrativo, vol. 1, 4. a ed., Ariel, Barcelona, 1996.

Leonard PEIKOFF, The ominous parallels, Meridian, New York, 1982.

Julián PELÁEZ DEL POZO, Tratado teórico-práctico de la organización, competencia y procedimientos en materias contencioso-administrativos, Imprenta D. B. González, Madrid, 1849.

Antonio PÉREZ HERNÁNDEZ, Naturaleza jurídica del recurso de agravios, Publicaciones del Consejo de Estado, Madrid, 1954.

José María PI Y SUNER, Lo contencioso-administrativo, versión taquigráfica revisada, completada y anotada del curso profesado en la Facultad de Derecho de la Universidad de Barcelona, Centro de Administración Municipal, Barcelona, 1928.

Giorgio PINO, "Diritti soggettivi”, capítulo 4, en A. SCHIAVELLO y V. VILLA (dir.), Filosofia del diritto. Introduzione critica al pensiero giuridico e al diritto positivo, Giappichelli, Torino, 2013.

José POSADA HERRERA, prólogo a J. GALLOSTRA Y FRAU, Lo contencioso-administrativo, Imprenta y fundición Manuel Tello, Madrid, 1881, pp. IV-XXIII.

Oreste RANELLETTI, A proposito di una questione di competenza della IV Sezione del Consiglio di Stato, Avezzano, Angelini, 1892.

Luis RECASENS SICHES, Tratado general de Filosofía del Derecho, Porrua, 3. a ed., México D. F., 1965.

Jean RIVERO, "Le huron au Palais Royal ou réflexions sur le récours pour excés de pouvoir", Dalloz, Chroniche, VI, 1962, pp. 37-40.

—, Droit administratif, 12a ed., Dalloz, Paris, 1987.

Stefano RODOTÀ, El terrible derecho: estudios sobre la propiedad privada, Civitas, Madrid, 1987.

Santi ROMANO, Fragmentos de un diccionario jurídico, Ediciones jurídicas Europa-América, Buenos Aires, 1964 (original de 1947).

Paul ROUBIER, Droit subjectifs et situations juridiques, Dalloz, Paris, 1963.

Antonio ROYO VILLANOVA, Elementos de Derecho administrativo, 2. t., 17. ${ }^{a}$ ed. corregida y aumentada con la colaboración de su hijo Segismundo, Librería Santarén, Valladolid, 1942.

Ramón SALAS CORTÉS, Lecciones de Derecho público constitucional, CEPC, Madrid, 1982 (original de 1821).

Vicente SANTAMARÍA DE PAREDES, Curso de Derecho administrativo, 8. a ed., Imprenta española, Madrid, 1914.

Juan Alfonso SANTAMARÍA PASTOR, "Sobre el origen y evolución de la reclamación administrativa previa”, RAP, núm. 77, 1975, pp. 81-180.

—, Sobre la génesis del Derecho administrativo español en el Siglo XIX (1812-1845), Iustel, Madrid, 2006 (original de 1972).

Salvatore SATTA, "Interesse ad agire e legitimazione", Il Foro italiano, vol. 77, núm. 8, 1954, pp. 169178.

Friedrich Karl von SAVIGNY, Sistema del Derecho romano actual, Góngora y Compañía, Madrid, 1878 (original de 1840-1849).

Eberhard SCHMIDT-ASSMANN, La teoría general del Derecho administrativo como sistema, Marcial Pons, 2003.

Silvie SCHMITT, "L'evolution de la subjectivisation du contentieux administratif en France et en Italie", Liber amicorum Jean-Claude Escarras: la communicabilité entre les systèmes juridiques, Bruylant, Bruxelles, 2005, pp. 956-967.

Enrique SERRANO GUIRADO, "La justicia administrativa”, RAP, núm. 6, 1951, pp. 143-162.

Domenico SORACE, "Promemoria per una nuova voce 'atto amministrativo", en Scritti in onore di Massimo Severo Giannini, t. III, Giuffrè, Milano, 1988, pp. 47 y ss.

Bernardo SORDI, Giustizia e amministrazione nell'Italia liberale. La formazione della nozione di interesse legittimo, Giuffrè, Milano, 1985.

Francisco SOSA WAGNER, Maestros alemanes del Derecho público (II), Marcial Pons, Madrid, 2004.

Aldo TRAVI, Lezioni di giustizia amministrativa, Giappichelli, Torino, 2012. 
Dolores UTRILLA FERNÁNDEZ-BERMEJO, "La relación jurídica en el sistema de Derecho administrativo", Revista de Derecho público: teoría y método, vol. 2, 2020, pp. 73-118.

Diego VAIANO, Pretesa di provvedimento e processo amministrativo, Giuffrè, Milano, 2002.

Reiner WAHL, Los últimos cincuenta años de Derecho administrativo alemán, Marcial Pons, Madrid, 2013.

Bernhard WEGENER, "Subjective Public Rights-Historical Roots versus European and Democratic Challenges", en H. PÜNDER y Ch. WALDHOFF (ed.), Debates in German Public Law, Hart Publishing, Oxford, 2014, pp. 219-238.

Bernhard WINDSCHEID, Die Actio des römischen Civilrechts, vom Standpunkte des heutigen Rechts, Julius Buddeus, Düsseldorf, 1856.

Gustavo ZAGREBELSKY, Il diritto mite, Einaudi, Torino, 1992. 